\title{
Sugarcane (Saccharum X officinarum): A Reference Study for the Regulation of Genetically Modified Cultivars in Brazil
}

\author{
Adriana Cheavegatti-Gianotto • Hellen Marília Couto de Abreu • Paulo Arruda • \\ João Carlos Bespalhok Filho • William Lee Burnquist • Silvana Creste • \\ Luciana di Ciero - Jesus Aparecido Ferro - Antônio Vargas de Oliveira Figueira • \\ Tarciso de Sousa Filgueiras • Mária de Fátima Grossi-de-Sá • Elio Cesar Guzzo • \\ Hermann Paulo Hoffmann - Marcos Guimarães de Andrade Landell • \\ Newton Macedo • Sizuo Matsuoka • Fernando de Castro Reinach • Eduardo Romano • \\ William José da Silva • Márcio de Castro Silva Filho • Eugenio César Ulian
}

Received: 6 October 2010 /Accepted: 13 January 2011 /Published online: 22 February 2011

(C) The Author(s) 2011. This article is published with open access at Springerlink.com

\begin{abstract}
Global interest in sugarcane has increased significantly in recent years due to its economic impact on sustainable energy production. Sugarcane breeding and better agronomic practices have contributed to a huge increase in sugarcane yield in the last 30 years. Additional increases in sugarcane yield are expected to result from the use of biotechnology tools in the near future. Genetically modified (GM) sugarcane that incorporates genes to
\end{abstract}

Communicated by: Marcelo C. Dornelas

A. Cheavegatti-Gianotto $\cdot$ H. M. C. de Abreu $\cdot$ S. Matsuoka

E. César Ulian $(\square)$

CanaVialis/Alellyx S.A., Rua James Clerk Maxwell,

320, 13069-380 Campinas, São Paulo, Brasil

e-mail: eugenio.c.ulian@monsanto.com

A. Cheavegatti-Gianotto

e-mail: adriana.cheavegatti@alellyx.com.br

S. Matsuoka

e-mail: sizuo.matsuoka@gmail.com

P. Arruda

Centro de Biologia Molecular e Engenharia Genética,

Universidade Estadual de Campinas,

13083-875 Campinas, São Paulo, Brasil

J. C. Bespalhok Filho

Universidade Federal do Paraná,

Rua dos Funcionários, 1540, Cabral,

80035-050 Curitiba, Paraná, Brasil

W. L. Burnquist

Centro de Tecnologia Canavieira,

CP 162, 13400-970 Piracicaba, São Paulo, Brasil increase resistance to biotic and abiotic stresses could play a major role in achieving this goal. However, to bring GM sugarcane to the market, it is necessary to follow a regulatory process that will evaluate the environmental and health impacts of this crop. The regulatory review process is usually accomplished through a comparison of the biology and composition of the GM cultivar and a nonGM counterpart. This review intends to provide informa-

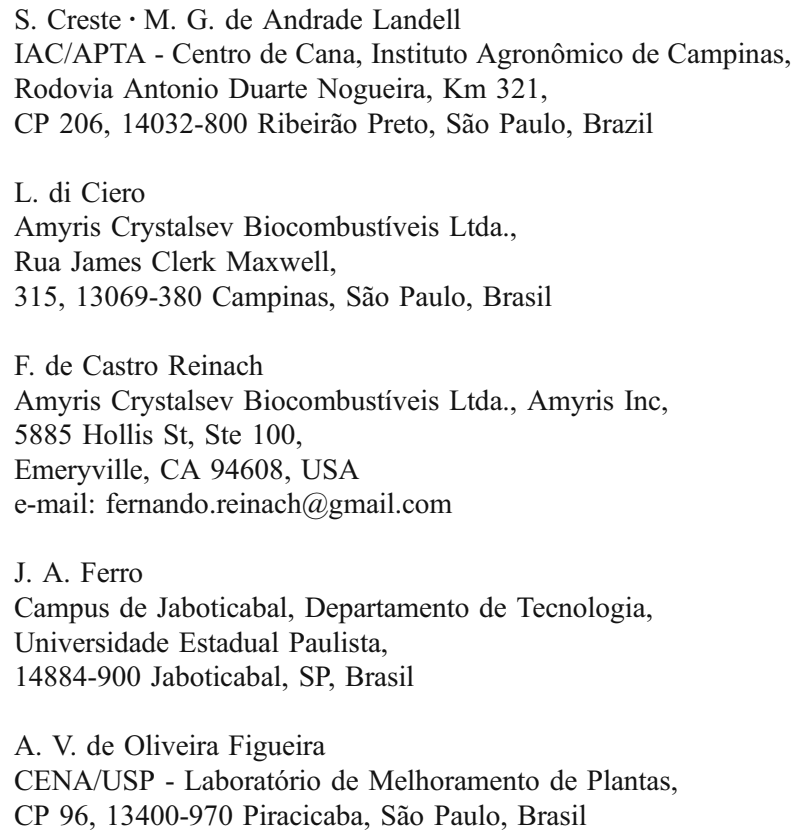


tion on non-GM sugarcane biology, genetics, breeding, agronomic management, processing, products and byproducts, as well as the current technologies used to develop GM sugarcane, with the aim of assisting regulators in the decision-making process regarding the commercial release of GM sugarcane cultivars.

Keywords Biosafety $\cdot$ Ethanol $\cdot$ Biofuel $\cdot$ Saccharum . Sugarcane

\section{Introduction}

Economic interest in sugarcane has increased significantly in recent years due to the increased worldwide demand for sustainable energy production. The Brazilian experience in sugarcane ethanol production has paved the way for the establishment of a consolidated world supply to meet the demand of a proposed ethanol addition of approximately $10 \%$ to gasoline worldwide. It is estimated that the Brazilian production of sugarcane must double in the next decade to meet this goal. In the future, biotechnological advances might help to reduce the environmental impacts of increased sugarcane production by developing solutions that would produce more sugarcane with decreased requirements for fertilizers and water. Among these solutions, GM sugarcane will play a key role in providing growers with more productive and resistant varieties. In Brazil, the National Biosafety Technical Commission (CTNBio) has already approved field trials with genetically modified sugarcane, incorporating traits such as increased yield, drought tolerance, insect resistance and herbicide tolerance. It is expected that the enormous research and development efforts being conducted by government and private

T. de Sousa Filgueiras

Reserva Ecológica do IBGE,

CP 08770, 70312-970 Brasília, Distrito Federal, Brazil

M. d. F. Grossi-de-Sá

Embrapa Recursos Genéticos e Biotecnologia,

Parque Estação Biológica,

Av. W5 Norte, 70770-900,

CP 02372 Brasília, Distrito Federal, Brasil

\section{E. Romano}

Embrapa Recursos Genéticos e Biotecnologia,

Empresa Brasileira de Agropecuária,

Av. W5 Norte, 70770-900,

CP 02372 Brasília, Distrito Federal, Brasil

E. C. Guzzo

Embrapa Tabuleiros Costeiros, Unidade de Execucao de Pesquisa, BR 104 Norte, Km 85, 57061-970,

CP 2013 Maceió, Alagoas, Brasil institutions will in the medium-term result in commercial release in Brazil of genetically modified sugarcane.

This review was produced to serve as a source of baseline information of conventional sugarcane to assist in the decision-making process related to possible future commercial release of GM sugarcane cultivars. Here, we will cover the origin of the species that have contributed to the genetic makeup of modern sugarcane cultivars, the agronomic behavior and growth habit of sugarcane, the botanical aspects of its reproductive biology, its genetic composition, potential for lateral gene transfer by pollen, its model of seed dispersion, and allergenicity of its derived products. This review also addresses the utilization of sugarcane and the byproducts generated by the sugarcane agribusiness.

\section{Economic Importance}

The sugarcane crop has been relevant to the Brazilian economy since the beginning of the 16th century. The first sugarcane plants were brought from Madeira Island and established in Brazil around 1515; the first sugar mill was established in 1532. Currently, Brazil is the world's largest sugarcane producer, with approximately 7.5 million cultivated hectares, which produced approximately 612 million tons in the 2009/2010 crop season. Approximately half of the sugarcane was used to produce sugar, and the remainder was used to produce 25 billion liters of ethanol (CONAB 2009). Brazil also produces sugarcane for animal feed, cachaça (sugarcane spirit), and sugarcane syrup, among other products.

In 2009, Brazil's sugar and ethanol exports generated approximately US\$ 9.9 billion in revenue, ranking sugarcane third among its exports (CONAB 2009).

\section{H. P. Hoffmann}

Campus de Araras, Universidade Federal de São Carlos,

Rodovia Anhanguera, Km 174,

CP 153, 13600-970 Araras, São Paulo, Brasil

N. Macedo

Araujo \& Macedo Ltda.,

Rua Oswaldo Cruz, 205, Jardim Santa Cruz,

13601-252 Araras, São Paulo, Brasil

e-mail: newton_macedo@yahoo.com.br

W. J. da Silva

Dow Agroscience, Rodovia Anhanguera,

Km 344,

Jardinópolis 14680-000 São Paulo, Brasil

M. de Castro Silva Filho

Departamento de Genética, Escola Superior de Agricultura Luiz

de Queiroz, Universidade de São Paulo,

Avenida Pádua Dias, 11,

CP 83, 13400-970 Piracicaba, São Paulo, Brasil 
Currently, the Brazilian sugar-ethanol agribusiness is experiencing a period of excitement due to the combination of extremely favorable factors, including prospects for the growth of internal and external markets, a long-term trend of rising international oil prices, possession of the world's lowest ethanol production costs, growth of the flex fuel fleet, and a universal concern for sustainable energy alternatives. These conditions have attracted global attention to the Brazilian fuel ethanol program and the country's potential to supply a significant part of the world's demand for renewable fuel. The result has been a substantial increase in sugarcane production over the last few years. In 2007, the planted area grew by $12 \%$ over the previous year and the same level of growth is expected for the next several decades (FNP 2009).

\section{Geographical Distribution}

Sugarcane is grown in all tropical and subtropical regions of the world, on both sides of the equator, up to approximately $35^{\circ} \mathrm{N}$ and $35^{\circ} \mathrm{S}$ (van Dillewijn 1952; Gomes and Lima 1964). In 2007, the main sugarcane-producing countries were Brazil (33\% of the world's production), India $(23 \%)$, China (7\%), Thailand (4\%), Pakistan (4\%), Mexico (3\%), Colombia (3\%), Australia (2\%), the United States $(2 \%)$ and the Philippines (2\%) (FNP 2009).

In Brazil, sugarcane cultivation is concentrated in the southeastern region, which is responsible for approximately $70 \%$ of the national sugarcane production (Fig. 1). Northeastern Brazil, another traditional producing area, is responsible for $14 \%$ of sugarcane production, and midwestern Brazil, where the crop is rapidly advancing, represents $13 \%$ of the national production (CONAB 2009). It should be noted that, despite the concerns about the expansion of sugarcane cultivation toward the Amazon region, the actual cultivation in this region is minimal and decreasing.

\section{Classification and Nomenclature}

The genus Saccharum was first described by Linnaeus (1753) in his book Species Plantarum. The generic name is derived from the Greek word sakcharon, which means sugar and was duly Latinized by the author. The book described two species: Saccharum officinarum L. and S. spicatum L., which is currently classified under the genus Perotis ( $P$. spicata (L.) T. Durand and H. Durand) (Dillon et al. 2007).

The taxonomy and nomenclature of the genus has always been challenging (Bentham 1883; Hackel 1883; Pilger 1940; Hitchcock 1951; Bor 1960; Almaraj and Balasundaram 2006). The genus has two known synonymous names, Saccharophorum and Saccharifera. When it was initially described, the genus consisted only of five to ten species from the Old World, including S. officinarum, S. spontaneum, S. sinense, S. edule and $S$. barberi. Later, several species that were allocated in other genera, including Andropogon, Anthoxanthum, Eriochrysis, and Erianthus, were transferred to Saccharum. The case of Erianthus is particularly interesting.

Currently, the genus Erianthus comprises species from the Old World and New World that were previously separated into two different genera since the Old World species were firstly placed under the genus Ripidium (Grassl 1971). Later, authors classified the Old World species under Erianthus, section Ripidium (Almaraj and Balasundaram 2006). This distinction is supported by the fact that the Old World species contain a flavonoid (di-C-glycoside) that is absent in New World species (Williams et al. 1974). Cordeiro et al. (2003), analyzing these two groups by microsatellites
Fig. 1 Sugarcane production in regions of Brazil (Source: Conab 2009)

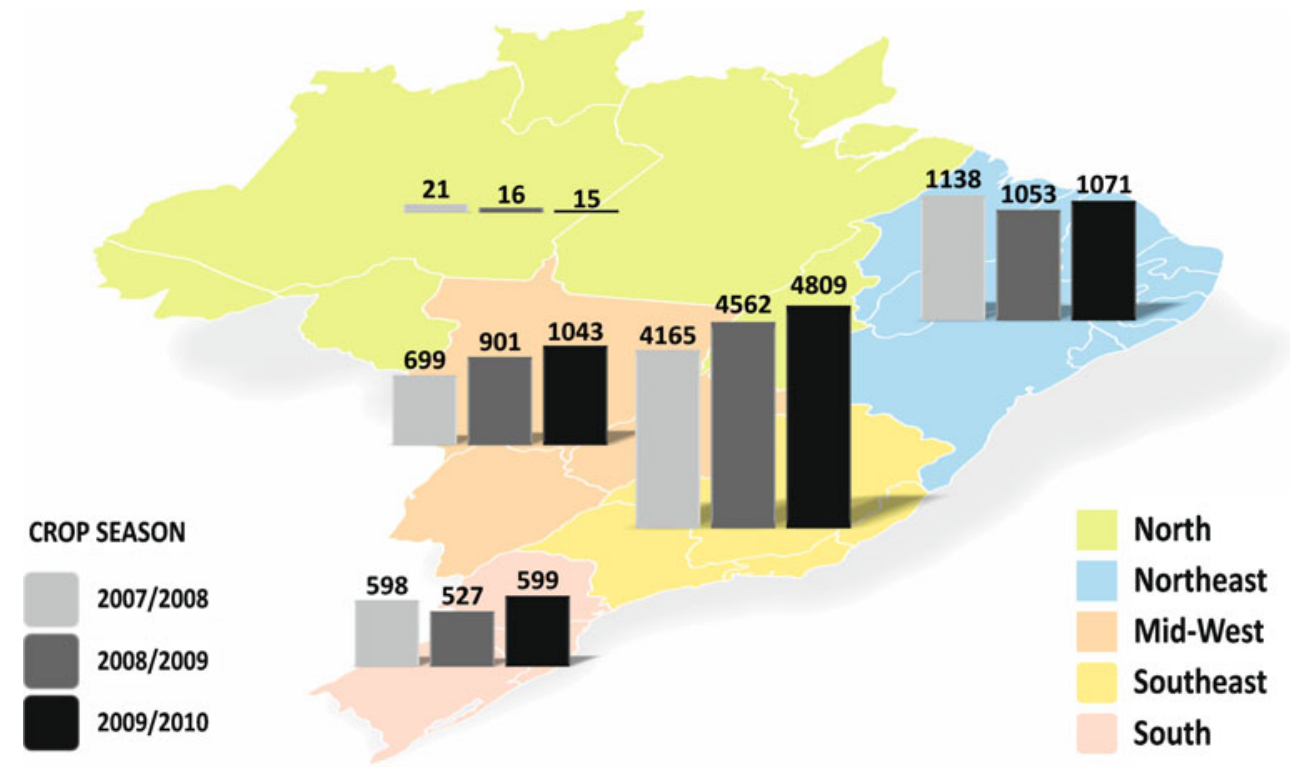


markers also found that Erianthus accessions clustered separated in accordance to their geographical origin.

Erianthus is considered to be closely related to Saccharum and many species have been assigned to either of these genera, depending on the criteria used. Several botanists, however, have considered that they are distinct genera (Hooker 1896; Haines 1921, Jeswiet 1925; Grassl 1946; Dutt and Rao 1950; Mukherjee 1958). This distinction has been reinforced by studies using the presence of root tip tannin (Rao et al. 1957), leaf lipoid (Vijayalakshmi and Rao 1963), esterase isozyme alleles (Waldron and Glasziou 1972), and flavonoid composition (Williams et al. 1974) and microsatellites markers (Cordeiro et al. 2003).

Despite these data, the genera and species are more often separated and identified primarily on the basis of floral characteristics, which are considered by botanists to be more stable than vegetative morphological characters and the basic criterion used to differentiate both genera is the presence (in Erianthus) or absence (in Saccharum) of a floret structure called an awn, which is an extension of the mid-rib of the floral bract, on the top of lemma II or the upper lemma. The lemma in which the awn is absent is referred to as awnless. The current trend regards Erianthus as synonymous with Saccharum because this commonly used criterion to differentiate both genera (presence/absence of awn on the lemma) is variable and is not a consistent characteristic in the complex (Bor 1960; Renvoize 1984; Clayton and Renvoize 1986). Therefore, the genus Saccharum currently comprises all species that were previously described under Erianthus. The current sugarcane botanical classification is shown in Table 1.

The tribe Andropogoneae consists of tropical and subtropical grass species that are grown in the Old World and New World. The most important cultivated members of the tribe are corn (Zea mays) and sorghum (Sorghum bicolor) (Daniels and Roach 1987). Saccharum and Sorghum share many similarities in their genetic composition, as they originated from a common ancestral lineage that diverged approximately

Table 1 Current sugarcane classification

\begin{tabular}{|c|c|}
\hline Order: & Poales \\
\hline Family: & Poaceae \\
\hline $\begin{array}{l}\text { Sub- } \\
\text { family: }\end{array}$ & Panicoideae \\
\hline Tribe: & Andropogoneae \\
\hline $\begin{array}{l}\text { Sub } \\
\text { Tribe: }\end{array}$ & Saccharinae \\
\hline Genus: & Saccharum \\
\hline Species: & $\begin{array}{l}\text { Saccharum officinarum; Saccharum spontaneum; } \\
\text { Saccharum sinense; Saccharum barberi; Saccharum } \\
\text { robustum; Saccharum edule (Old World). Saccharum } \\
\text { villosum; Saccharum asperum (New World) and others. }\end{array}$ \\
\hline
\end{tabular}

5-8 million years ago (Al-Janabi et al. 1994; Guimarães et al. 1997; Figueira et al. 2008).

\section{Botanical Description}

The currently cultivated sugarcane plants are hybrids derived from crossings mainly between plants of $S$. officinarum and S. spontaneum (Dillon et al. 2007). The plants are perennial grasses that form stools of stalks or culms that can be several meters in length and are juicy, with high concentrations of sucrose.

The sugarcane root system consists of adventitious and permanent shoot root types. Adventitious roots emerge from the culm root zone and are responsible for water uptake during bud sprouting and plant support until the permanent roots develop. Permanent roots are fasciculated at the base of growing shoots and are classified into support or anchor roots and the more network like absorption roots. (Mongelard 1968; Thompson 1964; Moore and Nuss 1987). The ratio between one root type and another are somewhat species specific. Saccharum officinarum generally contains fewer support roots than does $S$. spontaneum (Moore 1987a), which could explain the increased vigor and resistance to environmental stresses characteristic of $S$. spontaneum.

The stalk or culm consists of alternating nodes and internodes. On the node, there is a leaf scar, an axillary bud and a circumferential band of axillary root primordia. Stalk morphology is highly variable from one genotype to another and represents an important element for varietal characterization (Martin 1961). Sugarcane leaves are alternate and are attached to the stalk, with one leaf per internode. Sheathes consist of the sheath proper and the much smaller acropetal blade joint consisting of a leaf collar, dewlap, ligule and auricles. The shape, size and

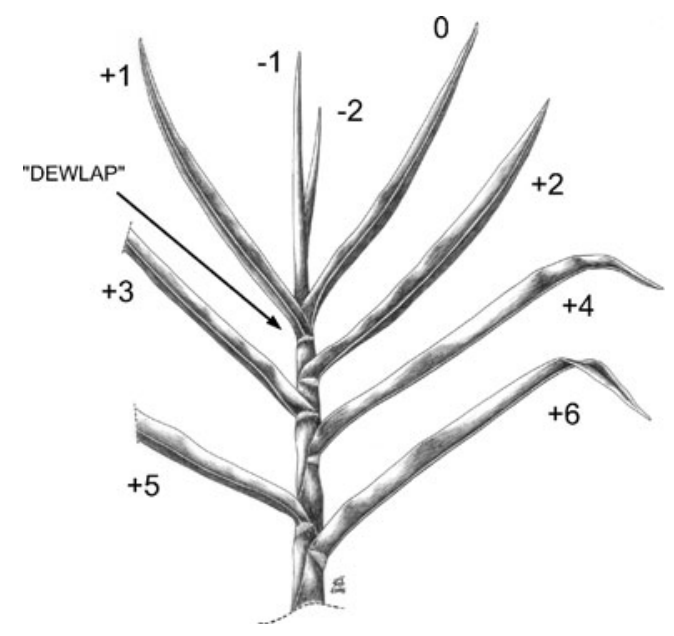

Fig. 2 Kuijper's leaf numbering system (1915) 
Fig. 3 Diagram of a sugarcane propagule: a evident propagule, cupulate coma, empty pedicel and rachilla plus sessile spikelet. The other figures depict the different parts of the spikelet. $\mathbf{b}$ Glume I. c Glume II. d Palea. e Flower with two lodicules, three stamens, and gynoecium with ovary and two feathered stigmas (Illustration: Klei Sousa)
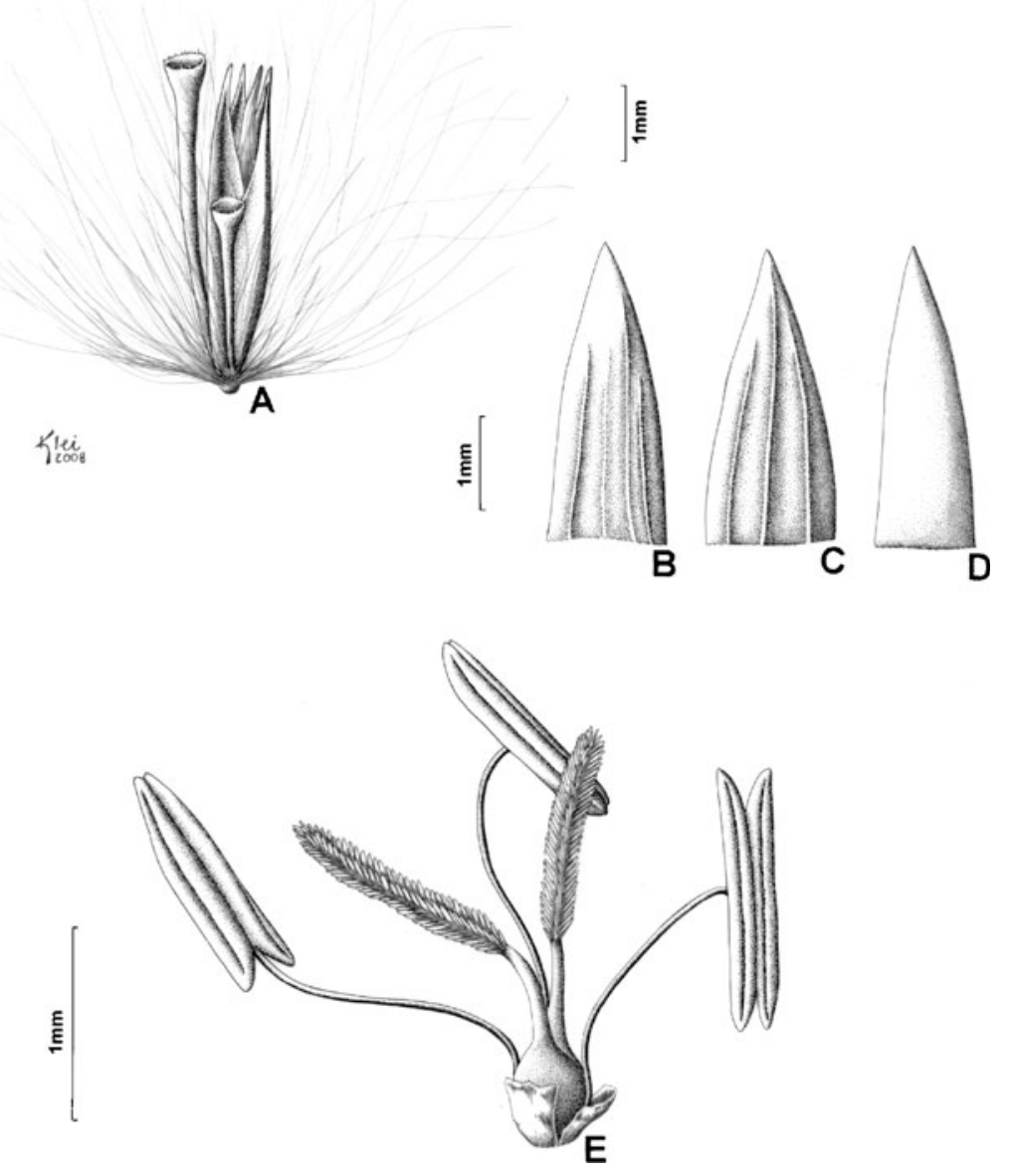

distribution of trichomes and the shape of the ligule and auricles are traits of taxonomic importance for varietal identification. Sugarcane leaves are numbered from top to bottom starting with the uppermost leaf showing a visible dewlap designated as leaf +1 (Fig. 2) (Moore 1987a).

The inflorescence of sugarcane is a ramified, conoidal panicle with a main stem, called the rachis, which is the continuation of the last stalk internode. The rachis holds secondary branches which in turn hold tertiary branches. The spikelets are located at the base of the tertiary branches and on the top of the secondary branches. Each spikelet has one flower, which is disposed alternately along the inflorescence secondary and tertiary branches. At the base of the spikelet, there is a ring of silky, colorless trichomes ('coma') that covers the spikelet (Fig. 3a) and help with spikelet dispersion. Next, there is a series of bracts called glumes ('glume I' and 'glume II'), both glabrous (Fig. 3b and c); upper lemma (or fertile lemma); and palea, which is hyaline and without veins and may be either rudimentary or absent (Fig. 3d). When the inflorescence matures, an anemochoric (by wind) dispersion of the propagules begins. The propagules consist of the coma, some floral clusters and the spikelet (Fig. 3a). The flowers (Fig. 3e) consist of two lodicules, the androecium and the gynoe-

cium. The pollen grains are spherical when fertile and prismatic when sterile. Sugarcane fruit, called the caryopsis (Fig. 4), is dry, indehiscent and one-seeded, and it cannot be separated from the seed. The fruit can only be distinguished from the seed when viewed with scanning electronic microscopy.

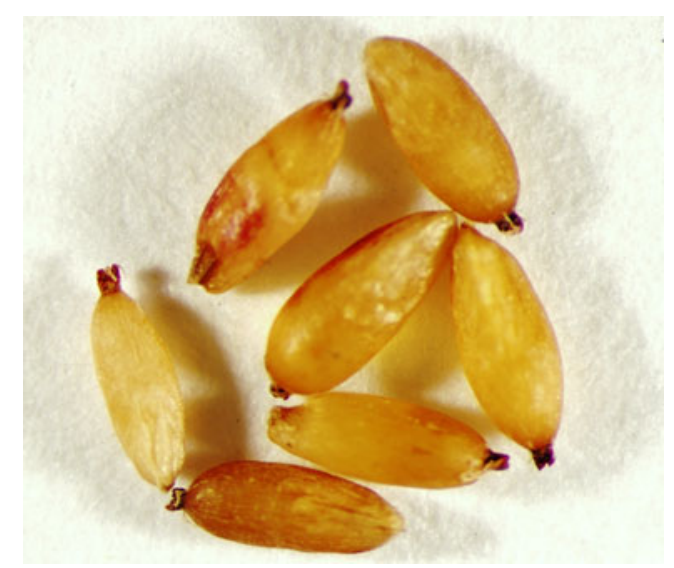

Fig. 4 Sugarcane caryopses. Note the presence of the remains of styles at the tip of the caryopsis and the differentiated embryo region (at the opposite extremity of the style remains) (Photograph: Alellyx) 


\section{Hybridization and Introgression}

Modern sugarcane cultivars are the products of crosses between species of the genus Saccharum that were made by breeders in the late 19th century (Matsuoka et al. 1999). The most important species contributing to modern sugarcane varieties were $S$. officinarum, which was widely cultivated for its ability to accumulate sucrose in its stalks, and $S$. spontaneum, which is a vigorous, widely adapted wild species which contributed genes for disease and stress resistance. The species $S$. sinense, $S$. barberi and $S$. robustum also provided minor contributions toward the development of some modern sugarcane varieties.

S. officinarum L. is generally known as the noble cane because it is stout and produces abundant sweet juice. Culms are thick (normally over $3.5 \mathrm{~cm}$ in diameter) and soft due to low fiber content. Assessions of this species display long, wide leaf blades $(1 \mathrm{~m}$ long $\times 5 \mathrm{~cm}$ wide) and a relatively small, shallow root system (Scarpari and Beauclair 2008). S. officinarum is highly demanding in specific climate conditions, high soil fertility and water supply. S. officinarum accessions are generally susceptible to diseases such as mosaic, gummosis, leaf scorch, root rot and Fiji disease (Martin 1961; Ricaud and Autrey 1989; Ricaud and Ryan 1989), but they tend to be resistant to sugarcane smut (Segalla 1964). S. officinarum includes all old traditional sugarcane varieties that were cultivated throughout the world prior to the introduction of hybrid varieties (Segalla 1964).

Known as wild sugarcane, S. spontaneum L. is highly polymorphic, with plant stature ranging from small grasslike plants without stalks to plants over $5 \mathrm{~m}$ high with long stalks. Leaf blades vary in width from very narrow mostly restricted to the mid-rib or up to a width of $4 \mathrm{~cm}$ (Matsuoka et al. 1999). Plants show highly adaptive plasticity and are found in different environments. $S$. spontaneum is the species that has contributed to the improvement in sugarcane vigor, hardness, tillering, ratooning ability and resistance to biotic stresses (Mohan Naidu and Sreenivasan 1987). These plants tend to be immune to most diseases, including 'Sereh' and mosaic, but they are susceptible to sugarcane smut (Segalla 1964). In some regions of the world, such as the United States, $S$. spontaneum is considered a harmful invasive species (USDA 2008). In Brazil, it is considered an exotic and non-invasive plant (Instituto Horus 2008; Global Invasive Species Database 2008).

Saccharum sinense Roxb. and Saccharum barberi Jesw. are known as Chinese or Indian canes, as they were initially grown in China and India before the spread of modern varieties (Mohan Naidu and Sreenivasan 1987). Some taxonomists consider them a single species (Matsuoka et al. 1999), and according to more modern studies, they are natural hybrids between $S$. officinarum and $S$. spontaneum (Irvine 1999; D’Hont et al. 2002). Stems from both species are long (up to $5 \mathrm{~m}$ ), thin (approximately $2 \mathrm{~cm}$ in diameter) and fibrous, presenting long, fusiform internodes. The plants have a vigorous, well-developed root system and good tillering, which enables adaptation to poor and dry soil and allows the production of large volumes of biomass. However, both species have medium sugar content and early maturation. $S$. sinense and $S$. barberi tend to exhibit resistance to root diseases; some individuals are resistant to mosaic, immune to 'Sereh' disease, resistant to sugarcane borers and susceptible to sugarcane smut (Segalla 1964). Due to poor flowering and sterility of most genotypes of these species, they are rarely used in sugarcane breeding programs (Roach and Daniels 1987), although they may have contributed to the development of some modern varieties (Mohan Naidu and Sreenivasan 1987; Dillon et al. 2007).

S. robustum Brandes and Jeswiet ex Grassl represents wild sugarcanes adapted to broad environmental conditions. It possesses a high fiber content and vigorous stalks that are $2.0-4.4 \mathrm{~cm}$ in diameter and up to $10 \mathrm{~m}$ high, but like $S$. officinarum, it does not have rhizomes. The culms are hard and have little juice, are poor in sugar content and have a hard rind, a characteristic that is exploited to build hedges (Matsuoka et al. 2005; Mozambani et al. 2006). S. robustum tends to be highly susceptible to mosaic (Segalla 1964). Few current commercial cultivars have received a contribution from this species. However, there are reports of a successful program to broaden the genetic basis of the current varieties by introgressing $S$. robustum into Hawaiian sugarcane varieties (Mohan Naidu and Sreenivasan 1987).

\section{Centers of Origin and Diversity}

The genus Saccharum probably originated before the continents assumed their current shapes and locations. The genus consists of 35-40 species and has two centers of diversity: the Old World (Asia and Africa) and the New World (North, Central and South America). Asia has approximately 25 native species, North America six native species and four or five introduced species, and Central America has three or four native and some introduced species (Webster and Shaw 1995). Africa has two native and Australia have one naturalized species (Darke 1999; Bonnett et al. 2008).

The Brazilian Saccharum species have not been well characterized. Only regional floristic surveys have reported the presence of these species. One study described the native species $S$. asperum, S.angustifolium, S. purpureum, $S$. biaristatum, $S$. glabrinodis, $S$. clandestinus and $S$. villosum, but the authors commented that these species 
were poorly defined so that it is possible that they all might be variations of a single species (Smith et al. 1982). In fact, from the species listed on this work, only $S$. asperum, $S$. angustifolium and $S$. villosum are currently accepted scientific names (The Plant List 2010). In another study, the native species were identified as $S$. villosum, S. asperum and $S$. baldwinii (Filgueiras and Lerina 2001).

The Saccharum species involved in the development of modern sugarcane cultivars originated from Southeast Asia (Roach and Daniels 1987). Because S. officinarum and $S$. spontaneum are the major contributors to the genomes of modern varieties, the geographical origins of these species will be described in more detail.

S. officinarum has been cultivated since prehistoric times (Sreenivasan et al. 1987). It is believed that its center of origin is Polynesia and that the species was disseminated throughout Southeast Asia, where a modern center of diversity was created in Papua New Guinea and Java (Indonesia); this is the region where the majority of specimens were collected in the late 19th century (Roach and Daniels 1987).

The center of origin and diversity of $S$. spontaneum is the more temperate regions of subtropical India. However, because $S$. spontaneum can be grown in a wide range of habitats and altitudes (in both tropical and temperate regions), it is currently spread over latitudes ranging from $8^{\circ} \mathrm{S}$ to $40^{\circ} \mathrm{N}$ in three geographic zones: a) east, in the South Pacific Islands, Philippines, Taiwan, Japan, China, Vietnam, Thailand, Malaysia and Myanmar; b) central, in India, Nepal, Bangladesh, Sri Lanka, Pakistan, Afghanistan, Iran and the Middle East; and c) west, in Egypt, Kenya, Sudan, Uganda, Tanzania, and other Mediterranean countries. These zones roughly represent natural cytogeographical clusters because $S$. spontaneum tends to present a different number of chromosomes in each of these locations (Daniels and Roach 1987).

\section{Genetic Constitution}

Saccharum species present high ploidy levels. S. officinarum is octoploid $(2 \mathrm{n}=80)$ having $x=10$ chromosomes, which is the basic chromosome number of members of the Andropogoneae tribe (D'Hont et al. 1995; Cesnik and Miocque 2004; Nobrega and Dornelas 2006). S. spontaneum has $x=$ 8 chromosomes (D'Hont et al. 1996) but presents great variation in chromosome numbers with five main cytotypes: $2 \mathrm{n}=62,80,96,112$ or 128 (Daniels and Roach 1987; Sreenivasan et al. 1987).

Modern sugarcane cultivars, which were derived from the hybridization between these two species, are considered allopolyploid hybrids (Daniels and Roach 1987), with most exhibiting a $2 n+n$ constitution, representing two copies of the $S$. officinarum genome plus one copy of the $S$. spontaneum genome (Cesnik and Miocque, 2004). The $S$. officinarum genome usually duplicates when it is hybridized with $S$. spontaneum. This phenomenon facilitated the work of the first breeders because nobilization consisted of increasing the ratio of the $S$. officinarum to that of the $S$. spontaneum genome (Bremer, 1961). In situ hybridization studies have shown that the genomes of modern hybrids are composed of $10-20 \%$ of S. spontaneum chromosomes, 5$17 \%$ of recombinant chromosomes containing part of $S$. officinarum and part of $S$. spontaneum chromosomes and the remainder composed of $S$. officinarum chromosomes (Piperidis and D'Hont, 2001; D'Hont 2005).

The hybrids are usually aneuploid, with a prevalence of bivalents, a significant proportion of univalents and rare multivalent associations during meiosis (Daniels and Roach, 1987). Despite this genome complexity, evidence suggests a diploid-like mode of inheritance (Hogarth, 1987).

\section{The "Saccharum Complex" Theory}

It has been hypothesized that an intercrossing group named the "Saccharum complex" consisting of the genera Saccharum (including species previously classified under Erianthus sect. Ripidium), Sclerostachya, Narenga and Miscanthus sect. Diandra provided the basis for modern sugarcane varieties (Mukherjee, 1957; Roach and Daniels 1987; Daniels and Daniels, 1975). Saccharum officinarum was likely derived from crosses involving $S$. spontaneum, Miscanthus, S. arundinaceus (Syn: Erianthus arundinaceus) and S. robustum (Roach and Daniels, 1987). The presence of whole S. officinarum chromosomes, homologous to chromosomes from Miscanthus and from some Saccharum species previously classified as belonging to Erianthus sect. Ripidium, supports the hypothesis of hybridization among these species giving rise to Saccharum officinarum (Daniels and Roach, 1987; Besse et al., 1997).

Despite the fact that the aforementioned Saccharum complex hypothesis is currently broadly accepted, particularly by sugarcane breeders, who consider species within the "Saccharum Complex" as the primary gene pool for sugarcane breeding, recent molecular data do not support this theory (D'Hont et al. 2008). Thus, there is a suggestion that Saccharum is a well-defined lineage that diverged over a long evolutionary period from the lineages leading to the Erianthus and Miscanthus genera (Grivet et al. 2004).

\section{Sugarcane Breeding}

Sugarcane breeding is based on the selection and cloning of superior genotypes from segregating populations that was 
obtained by crossing contrasting individuals. To maximize the efficiency of this rather long process, it is divided into various phases, including choosing suitable parentals and quantifying environmental effects on the expression of the selection characters.

The first step of a sugarcane breeding program consists of establishing a germplasm collection in a heavy flowering area where the flowering time of the parental lines can be synchronized. To meet sugarcane flowering requirements, the breeding stations operating in Brazil are all located in the heavy flowering northeastern region and include the breeding programs of CanaVialis at Maceió (AL), Rede Interuniversitária para o Desenvolvimento do Setor Sucroalcooleiro - RIDESA at Murici (AL), Centro de Tecnologia Canavieira - CTC at Camamú (BA) and Instituto Agronomico de Campinas - IAC at Uruca (BA). Other sugarcane breeding programs have been active in Brazil in the past and the codes for identifying varieties developed in those programs are listed in Table 2.

A typical sugarcane variety development program (Fig. 5) begins by making a large number of crosses among selected parental genotypes. The resulting seeds give rise to a large number of progeny (seedlings), which are needed to increase the chance of obtaining improved cultivars from superior genetic combinations. The selection process is conducted in distinct locations to identify superior genotypes with improved agronomical performance and tolerance to biotic and abiotic stresses. On average, one commercial variety can be obtained for every 250,000 seedlings evaluated in the first stage of the breeding program (T1). The selection process continues in the second and third phases, which are evaluated under different environmental conditions (Fig. 5).

\section{Reproductive Biology}

Sugarcane flowering is regulated by day length known as the photoperiod. Flowering induction and development occur when the hours of light decreases from $12.5 \mathrm{~h}$ to $11.5 \mathrm{~h}$. Panicle emergence occurs with an additional decrease to approximately $11 \mathrm{~h}$. Under these conditions in the southern hemisphere, flowering occurs close to the autumnal equinox (March 21st) and is delayed by approximately 2 days for each additional degree of latitude (Brett, 1951; Moore and Nuss, 1987). Flowering induction is only effective after the juvenile period has been completed, i.e., when at least two to four internodes have matured (Clements and Awada, 1967; Coleman, 1969, Julien, 1973). Adequate water and temperatures above $18^{\circ} \mathrm{C}$ are also necessary (Barbieri et al., 1984; Coleman, 1969).

S. officinarum is refractory to flowering, which effectively occurs only at low latitudes. The low flowering percentage of S. officinarum is exploited as a beneficial agronomic trait of hybrid cultivars once flowering is undesirable since sugar yield decreases during flower development as flowering culms stop to grow, become diseased and, ultimately, senesce. (Moore and Osgood, 1989).

The optimal temperatures for panicle development and pollen fertility are $28^{\circ} \mathrm{C}$ during the day and $23^{\circ} \mathrm{C}$ at night. Temperatures below $23^{\circ} \mathrm{C}$ delay panicle development and reduce pollen fertility (Brett and Harding, 1974; Berding, 1981). Daytime temperatures above $31^{\circ} \mathrm{C}$ and nighttime temperatures below $18^{\circ} \mathrm{C}$ are detrimental (Clements and Awada, 1967; Moore and Nuss, 1987).

Sugarcane pollen is small, ca. $50 \mu \mathrm{M}$, with a honeycombed exine and is dispersed primarily by wind. Sugarcane pollen grains dry rapidly after dehiscence with an
Table 2 Main Brazilian sugarcane breeding programs

(*) Still in operation

\begin{tabular}{lll}
\hline Breeding Programs & Period & Abbreviation \\
\hline Escada, PE & $1913-1924$ & EB \\
Campos, RJ & $1916-1972$ & CB \\
Barreiros, PE & $1924-1933$ & EB \\
São Bento, Tapera, PE & $1928-?$ & SBP \\
Curado, Recife, PE & $1933-1974$ & (PB) - IANE \\
EECAPO, Piracicaba, SP & $1928-1935$ & \\
Agronomic Institute of Campinas, Campinas, SP & $\left.1935-{ }^{*}\right)$ & IAC \\
COPERESTE, Sertãozinho, SP & $1963-1969$ & COP \\
EECA, Rio Largo, AL & $1968-1971$ & \\
COPERSUCAR, Piracicaba, SP & $1968-2004$ & SP \\
CTC, Piracicaba, SP (former COPERSUCAR) & $\left.2004-{ }^{*}\right)$ & CTC \\
PLANALSUCAR, Brazil & $1971-1990$ & RB \\
Barra Plant, Barra Bonita, SP & $1975-1996$ & PO \\
Federal Universities, Brazil & $\left.1991-{ }^{*}\right)$ & RB \\
CanaVialis, Campinas, SP & $\left.2003-{ }^{*}\right)$ & CV \\
\hline
\end{tabular}


Fig. 5 Flowchart of a sugarcane breeding program. T1: seedling selection. T2: clone selection. T3: local trial. T4: regional trial. Source: CanaVialis

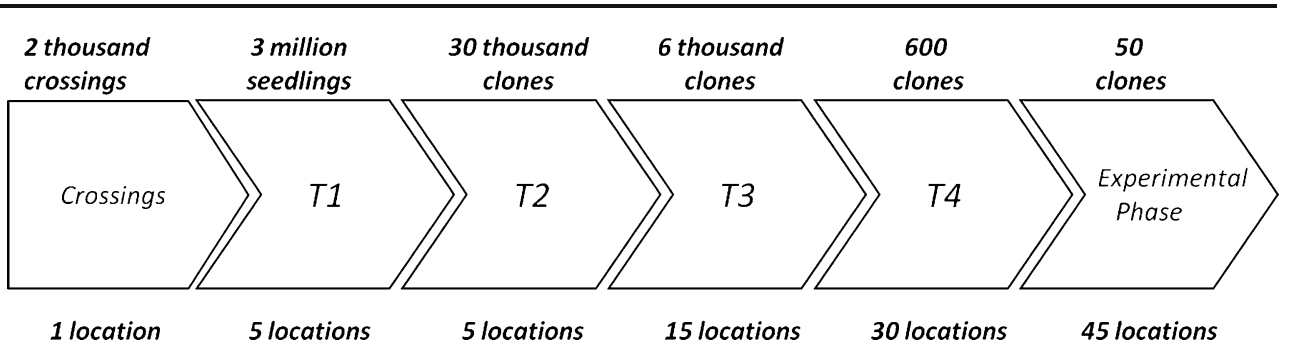

isolation cells, to avoid undesired cross-contamination. After 3-4 days for hybridization, fertilized panicles are kept in a shed for 1 week to promote seed maturation. Panicles are then harvested and placed in a heated chamber to dry the seeds (Ethirajan, 1987).

In a variety development program, sugarcane cultivars are selected for low flowering. However, because flowering is influenced by environmental conditions, flowering in cultivation fields may still occur in a given location or in a given year. If seeds are produced and fall onto the soil, germination only occurs under conditions of high temperature and humidity. Therefore, sexual reproduction is strongly compromised in locations that have a dry, cold autumn, such as southern Brazil and the southern parts of the southeastern and midwestern regions of Brazil. In the northern parts of the southeastern and midwestern regions, relative humidity but not nighttime temperature is normally restrictive. In general, some flowering may occur in the southern, southeastern and midwestern regions of Brazil, and in some years, it may even be intense. Nevertheless, because RAH is low heavy flowering does not mean that seedings are produced; even if seeds are formed, field conditions are very unfavorable for germination because of low soil humidity, since it is well knwn that sugarcane seeds lose approximately $90 \%$ of their viability after 80 days at $28^{\circ} \mathrm{C}$ (Rao, 1980). However, in the northeastern region, conditions are favorable for both flowering and seed

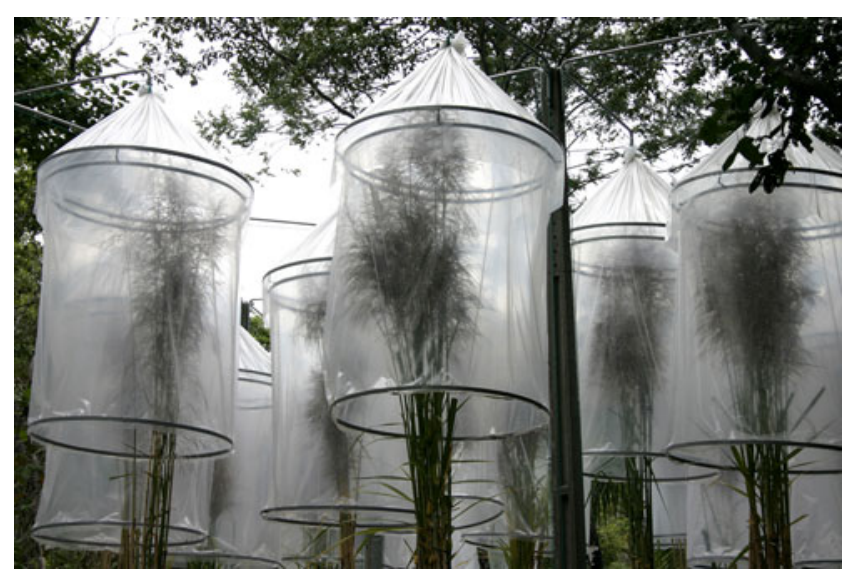

Fig. 6 Sugarcane crossing conducted under domes (lanterns). Source: CanaVialis 
formation. Seed dehiscence occurs during the wet season, which favors seed germination under field conditions.

\section{Potential for Lateral Gene Transfer}

Commercial sugarcane production is performed exclusively using vegetatively propagated material of comercial hybrids. Under ideal flowering conditions, sugarcane pollen is dispersed by wind, with no participation of animal or insect vectors (McIntyre and Jackson, 2001). Because sugarcane pollen has low viability, natural hybridization can only occur close to the pollen-supplying plant (Moore, 1976; Venkatraman, 1922). Thus, little seed set is expected since pollen rapidly loses its viability.

Although crossings between species of the genus Saccharum with other closely related species have been suggested to occur in the wild (Grassl 1980; Daniels and Roach, 1987), wild hybridization has not been reported with current sugarcane varieties.

Species belonging to the "Saccharum Complex" exhibit different levels of sexual compatibility with $S$. officinarum and S. spontaneum under artificial controlled crossings (Bonnett et al., 2008). Hybridization among sugarcane species and Erianthus sect. Ripidium and Miscanthus species are more probable than with Narenga and Sclerostachya under breeder's intervention. However, genetic transfer among commercial hybrids and these ancestral species, if existent, are much lower under natural conditions (Bonnett et al., 2008). It is important to note that there are no members of the "Saccharum Complex" species native in Brazil. In addition, there is no data on the biology of the wild Brazilian Saccharum species such as S. villosum, $S$. asperum, S. angustifolius and S. baldwinii (Filgueiras and Lerina, 2001; Kameyama, 2006; Carporal and Eggers, 2005) nor on the possibility of gene flow occurring between them and commercial sugarcane hybrids.

The Saccharum species that gave rise to commercial sugarcane varieties (S. officinarum and $S$. spontaneum, with minor contributions of $S$. robustum, $S$. barberi and $S$. sinense) are not native to Brazil. In Brazil, these species exist only in germplasm collections which are used in sugarcane breeding programs. Under breeding station conditions, they can flower synchronously and successfully hybridize with modern varieties. However, lateral transfer of genes among modern sugarcane hybrids and those species is not expected to occur under natural Brazilian environmental conditions.

\section{Commercial Sugarcane Cultivation}

The first step towards establishing a commercial sugarcane field is the production of vegetative planting material from the desired commercial variety under approved sanitary conditions at nurseries. To assure the starting material is disease-free, it is common practice that the stalks to be used as planting material are either exposed to thermotherapy (a hot water treatment to control systemic bacterial infections such as ratoon stunting disease), or they are obtained aseptically through meristem culture (free of bacteria and viruses), or from a combination of methods. Essentially, there are three types of nurseries differing primarily in size and generations removed from initial asepsis:

- Basic Nursery or Pre-Primary Nursery originates from buds of aforementioned treated stalks or meristem propagated plants.

- Primary Nursery originates from the Basic Nursery but is roughly ten times larger than that source. The first ratoon of the Basic Nursery is also considered a Primary Nursery.

- Secondary Nursery originates from the Primary Nursery and is $10-15$ times larger than the previous nursery. The second ratoon of the Basic Nursery and the first ratoon of the Primary Nursery can also be considered Secondary Nurseries (Xavier et al., 2008).

Commercial plantations are generally established using time proven conventional methods. Plowing is $30 \mathrm{~cm}$ deep, and the furrows cut to a depth of $25-30 \mathrm{~cm}$. Rows are spaced at distances varying from 0.8 to $1.5 \mathrm{~m}$ and are planted with $8-12$ tons of planting material per hectare. Stalks are distributed in furrows in pairs with the base of one stalk paired against the upper part of the other, i.e., two stalks are laid in opposite directions because the buds from the upper part of the stalk tend to germinate better than those of the base. After the stalks are distributed in the furrow, they are sectioned into 2 to 3 -node seed pieces to interrupt apical dominance that exists in the intact stalk. In soils known to be infested by insect pests or nematodes, pesticides are applied over the cuttings in the furrows. The last step of the planting operation is to cover the cuttings in the furrows with 10$15 \mathrm{~cm}$ of soil (dos Anjos and Figueiredo, 2008).

In Brazil, the use of irrigation in commercial sugarcane fields is generally not necessary, contributing to low production costs. Currently, as marginal production areas, primarily drier areas with inadequate rainfall, are added to the sugarcane industry through crop expansion, drought tolerance is seen as an increasingly important trait for sugarcane varieties (Pires et al., 2008).

When the crop begins to grow, the most important agronomic practice is weed control. Once an optimal plant stand is established, the major concern is to employ 
practices to insure good crop development to achieve good maturation, i.e. accumulation of sugar, in an optimal time span. Proper practices assure optimization of the harvesting-milling operations and, consequently, overall economic return. This aim is achieved by mills cultivating a range of varieties having different soil nutrient requirements, rates of maturation and reliable disease resistance.

In Brazil, sugarcane harvesting is either semi-mechanized or completely mechanized. In the first case, the cane is harvested manually, but it is loaded onto trucks mechanically; in the second case, the cane is harvested by machines that load it directly onto trucks. Although the fully mechanized harvest system has the advantage of not requiring a prior burning step, it cannot be adopted everywhere because current harvesting machines cannot operate in areas where the slope exceeds 1517\% (Ripoli and Ripoli, 2008).

\section{Commercial Sugarcane Crop Cycle}

Sugarcane is a semiperennial crop in commercial fields. It has to be replanted approximately every three to six harvests when grown under the rainfed conditions of Brazil. Replanting is required because of declining yields due to crop and soil damage caused by the heavy traffic of machines and trucks over the stumps during harvesting. In addition, there could be a progressive accumulation over time of pathogens in the sugarcane crop, some of which reduce stand population while others impair plant growth. There may also be a genetic component contributing to yield decline because most of the commercial cultivars have been selected to produce well only for the first three to four cultivation cycles. The overall result is a decrease in year-over-year productivity, which can reach economically unfeasible levels and the need to replant the field (Matsuoka et al., 1999).

There are two basic sugarcane production cycles. The plant-cane cycle starts with planting and ends after the first harvest. The ratoon, or ratoon-cane, cycle starts after the harvest of the plant cane and continues with successive ratoon crops until field renewal (Fig. 7). The complete cycle of a sugarcane field lasts either four or five seasons, after which time the crop is renewed. Eradication of the crop after it has become economically unfeasible is performed by ploughing it under and harrowing the soil, which is often preceded by the application of a systemic herbicide.

\section{Sugarcane-Associated Insects}

The most important sugarcane insect pests in Brazil are the sugarcane borers (Diatraea saccharalis and Diatraea flavipennella), the giant sugarcane borer (Telchin licus), spittlebugs (Mahanarva fimbriolata and Mahanarva posticata), termites (different genera), the migdolus beetle (Migdolus fryanus), the sugarcane weevil (Sphenophorus levis) and herbivorous ants (Atta spp. and Acromyrmex spp.).

$D$. saccharalis is widely distributed in Brazil, while $D$. flavipenella is restricted to the northeastern region of the country. Both species construct galleries in the stalks, leading to less biomass and sugar production, and an increase in fungal infections and juice contamination. These sugarcane borers are mainly controlled by massive release of the parasitoid Cotesia flavipes, which is normally reared in labs at the various mills. Sugarcane borers are also controlled, although by a lesser extent, by the release of the parasitic wasp Trichogramma galloi. Currently there is strong evidence that the sugarcane borer population has been increasing due to the expansion of cane into new areas, the cultivation of susceptible varieties, and the failure to use biological control. The increase in borer populations has been causing an increase in the use of pesticides to control these insects (Dinardo-Miranda, 2008a). The giant sugarcane borer ( $T$. licus) is another lepidopteran pest that attacks the crop. T. licus was considered to be restricted to northeastern Brazil, but there have been recent reports of its occurrence in São Paulo State, Brazil's main sugarcane producing state. T. licus also construct galleries in the stalks, but they more easily outright kill the ratoons due to the extensive damage caused by their large size (DinardoMiranda, 2008a). Biological and chemical control mechanisms against $T$. licus are not effective, and the economic impact of the pest, if it spreads throughout Brazilian sugarcane-producing regions, has yet to be assessed.

The root froghopper ( $M$. fimbriolata) has become an important sugarcane pest since Brazil started to abolish crop burning. Crop damage is caused by the young insect (nymph), which sucks water and nutrients from plant roots and injects toxins into them, leading to a decrease in root function and, consequently, a loss of productivity. Release of the fungus Metarhizium anisopliae results in good biological control, which can be complemented or replaced by pesticide spraying (Dinardo-Miranda, 2008a). The leaf spittlebug (M. posticata) is more predominant in northeastern Brazil; this insect sucks leaf sap, causing leaf drying; it can be controlled in the same way as M. fimbriolata.

There are many species of termites that attack sugarcane in the the country. Among these species, H. tenuis is the most harmful. These underground insects attack the stalks used for planting, leading to low bud germination and the need for replanting (Dinardo-Miranda, 2008a). Farmers control termites by spraying pesticides over the stalks in the furrow during planting.

The migdolus beetle Migdolus fryanus is a native Brazilian insect that attacks the roots of many crops, including sugarcane, coffee, eucalyptus and beans (Bento et al. 1985). The insect can destroy the root system, leading to an early 


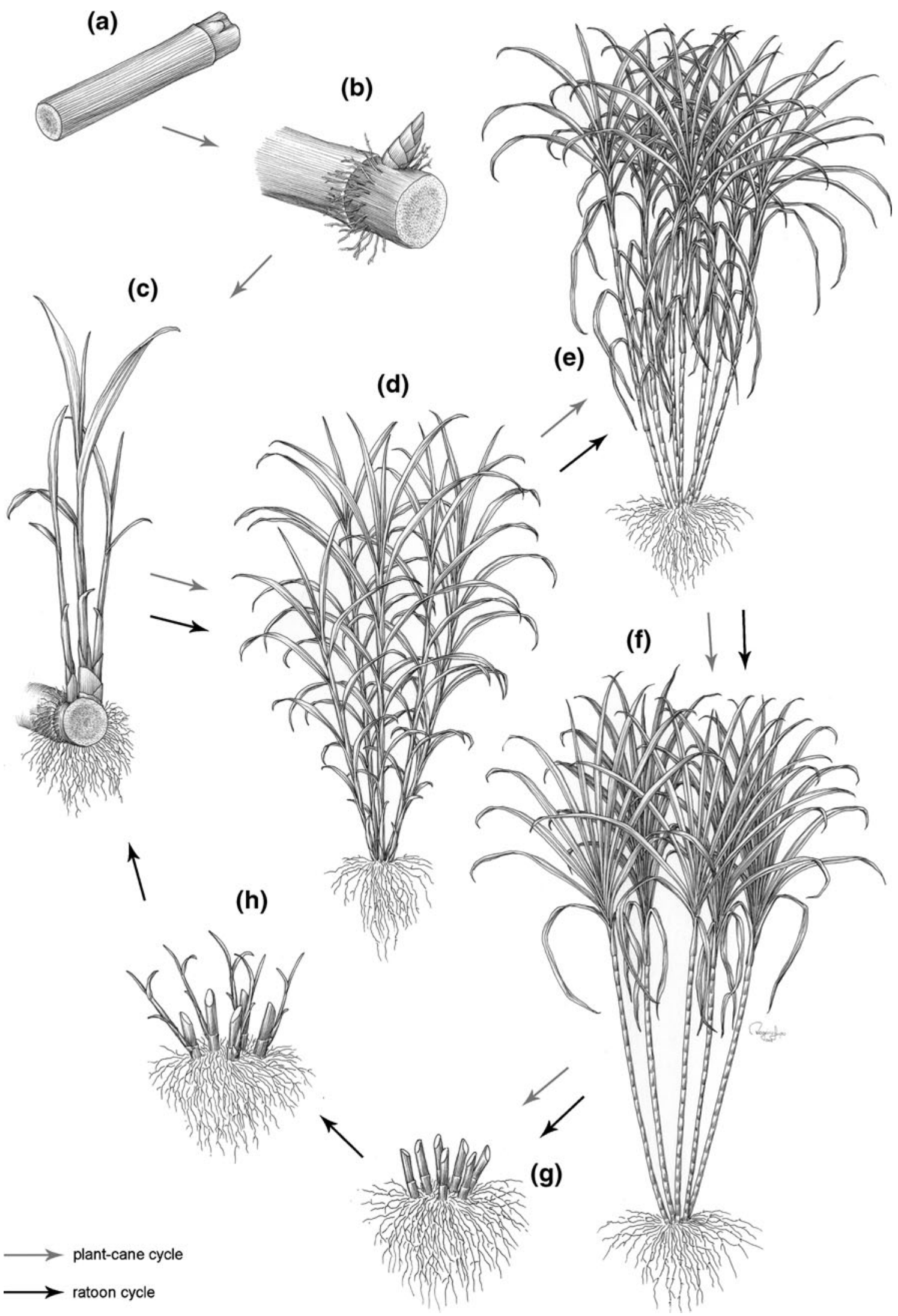

Fig. 7 Sugarcane phenological cycle. a Stalk pieces used in planting; b Beginning of bud sprouting and rooting; c Tillering initiation; d Intense tillering; e Beginning of maturation; $\mathbf{f}$ Manufacturable stalks in optimal sucrose concentration; g Harvesting; h Ratoon sprouting. Illustration: Rogério Lupo 
need for field replanting. Control of $M$. fryanus is difficult because the larvae live deep within the soil so that pesticide application during planting is not very effective. Recently, the use of pheromone traps has been shown to be very promising for controlling this pest (Nakano et al., 2002). The sugarcane weevil (Sphenophorus levis) is another beetle that attacks the sugarcane root system, leading to damage similar to that caused by the migdolus beetle. S. levis has low dissemination ability so its spread is linked to human activities (DinardoMiranda, 2008a). Consequently, one of the more effective control practices for this pest is to avoid planting cane that is harvested from infected areas.

Ants that behave as pests in the sugarcane crop belong to the genera Atta and Acromyrmex. The species Atta bisphaerica and Atta capiguara cause most of the losses, but Atta sexdens and Atta laevigata also cause damage. Studies have shown that the ants of one anthill can reduce sugarcane productivity by 3.2 ton $\mathrm{ha}^{-1}$ (Dinardo-Miranda, 2008a). Control of these pests is accomplished using pesticides that must be applied very carefully because the pesticides could kill predator ants that are beneficial to the crop.

Many species of nematodes are found in association with sugarcane, but in Brazil, most of the damage is caused by five species: Meloidogyne incognita, Meloidogyne javanica, Pratylenchus zeae, Pratylenchus brachyurus and Helycotylenchus dihystera. These nematodes are mainly controlled with chemical pesticides because nematoderesistant varieties have not been developed in the Brazilian sugarcane breeding programs (Dinardo-Miranda, 2008b). Nematicide application during sugarcane planting can increase productivity up to $30 \%$ in some infested areas (Copersucar, 1982). It is also possible to use nematocides

Table 3 Registered products to control insects and nematodes in sugarcane fields in Brazil. Source: AGROFIT (2010)

\begin{tabular}{|c|c|c|c|}
\hline Common name & Chemical group & Commercial name & Target organism ${ }^{2}$ \\
\hline $\begin{array}{l}(\mathrm{Z})-11- \\
\text { Hexadecenyl } \\
\text { acetate }\end{array}$ & unsaturated acetate & Bio Spodoptera & Spodoptera frugiperda \\
\hline $\begin{array}{l}\text { (Z)-7-dodecenyl } \\
\text { acetate }\end{array}$ & unsaturated acetate & Bio Spodoptera & S. frugiperda \\
\hline $\begin{array}{l}(\mathrm{Z})-9- \\
\text { tetradecenyl } \\
\text { acetate }\end{array}$ & unsaturated acetate & Bio Spodoptera & S. frugiperda \\
\hline Aldicarb & $\begin{array}{l}\text { oxime } \\
\text { methylcarbamate }\end{array}$ & Temik 150 & $\begin{array}{l}\text { Mahanarva fimbriolata, Meloidogyne incognita, } \\
\text { Pratylenchus zeae }\end{array}$ \\
\hline $\begin{array}{l}\text { Bacillus } \\
\text { thuringiensis }\end{array}$ & biological & Bac-Control WP, Dipel WP, Thuricide & S. frugiperda, Mocis latipes \\
\hline Bifentrin & pyrethroid & $\begin{array}{l}\text { Bistar } 100 \text { EC, Brigada EC, Brigade } 100 \text { EC, } \\
\text { Capture } 100 \text { EC, Capture } 400 \text { EC, Talstar } 100 \\
\text { EC }\end{array}$ & $\begin{array}{l}\text { Heterotermes tenuis, Migdolus fryanus, } \\
\text { Procornitermes triacifer }\end{array}$ \\
\hline Carbofuran & $\begin{array}{l}\text { benzofuranyl } \\
\text { methylcarbamate }\end{array}$ & $\begin{array}{l}\text { Carboran Fersol } 350 \text { SC, Diafuran 50, Furacarb } \\
100 \text { GR, Furadan } 100 \text { G, Furadan } 350 \text { SC, } \\
\text { Furadan } 50 \text { GR, Ralzer } 50 \text { GR }\end{array}$ & $\begin{array}{l}\text { Meloidogyne. javanica, M. incognita, } \\
\text { Helicotylenchus dihystera, P. zeae, M. } \\
\text { fimbriolata, Diatraea saccharalis, M. fryanus, } \\
\text { H. tenuis }\end{array}$ \\
\hline Endosulphan & cycledienochloride & $\begin{array}{l}\text { Dissulfan EC, Endosulfan Nortox } 350 \text { EC, } \\
\text { Endosulfan } 350 \text { EC Milenia, Endozol, Thiodan } \\
\text { EC }\end{array}$ & H. tenuis, M. fryanus, Cornitermes cumulans \\
\hline Ethiprole & phenylpyrazole & Curbix $200 \mathrm{SC}$ & H. tenuis, M. fimbriolata \\
\hline Fipronil & pyrazole & Regent 20 GR, Regent $800 \mathrm{WG}$ & $\begin{array}{l}\text { Neocapritermes opacus, } H \text {. tenuis, } P \text {. triacifer, } C \text {. } \\
\text { cumulans, D. saccharalis, M. fryanus }\end{array}$ \\
\hline Imidacloprid & neonicotinoid & $\begin{array}{l}\text { Confidor } 700 \text { WG, Evidence, Nuprid } 700 \text { WG, } \\
\text { Warrant }\end{array}$ & H. tenuis, M. fryanus, N. opacus, M. fimbriolata \\
\hline $\begin{array}{l}\text { Metarhizium } \\
\text { anisopliae }\end{array}$ & biological & Metarril Wp E9 & M. fimbriolata \\
\hline $\begin{array}{l}\text { N-2'S- } \\
\text { methylbutyl- } \\
\text { 2-methyl } \\
\text { butylamide }\end{array}$ & $\begin{array}{l}\text { amide } \\
\text { (pheromone) }\end{array}$ & Migdo & M. fryanus \\
\hline Terbufos & organophosphorate & Counter $150 \mathrm{G}$ & P. zeae, $M$. incognita, $H$. tenuis, $M$. javanica \\
\hline Thiametoxam & neonicotinoid & Actara $10 \mathrm{GR}$, Actara $250 \mathrm{WG}$ & M. fimbriolata, H. tenuis \\
\hline Trichlorfon & organophosphorate & Dipterex 500 & $\begin{array}{l}\text { M. latipes, S. frugiperda, Tomaspis furcata, } M \text {. } \\
\text { fimbriolata }\end{array}$ \\
\hline Triflumuron & benzoylurea & Certero & D. saccharalis \\
\hline
\end{tabular}


in ratoon cycles, but the control of nematodes on ratoons is not as effective (Dinardo-Miranda, 2008b). The pesticides that are registered in Brazil are displayed in Table 3.

In addition to insects that act as pests, sugarcane fields contain other associated insects with different biological functions, which comprise the sugarcane insect fauna (entomofauna). There have been several sugarcane entomofauna studies aimed at identifying the impact of sugarcane field burning on the associated insect crop population. These studies revealed a species rich system (Macedo and Araújo, 2000a; Macedo and Araújo, 2000b; Araújo et al., 2004; Araújo et al., 2005). However, identifying the risks to the insect fauna of adopting specific technologies, such as new agrochemicals and genetically modified cultivars for crop improvement requires detailed analyses of the individual species that are most important and meaningful for monitoring (Romeis et al., 2008). Species selection must be based on the biological functions of the insects, their abundance and their economic importance. Other, less objective criteria such aesthetic value, cultural value and species at risk, may also be used (Romeis et al., 2008).

Table 4 displays a no exhaustive list of insects and nematodes that are most relevant to the sugarcane agroecosystem.

\section{Sugarcane Weed Control}

Although sugarcane is a vigorous plant, the crop suffers from weed competition in its initial development stages. The most detrimental weed species are in the Poaceae and Cyperaceae families, but morning glory species may also interfere by coiling around the sugarcane plants, reducing leaf unfurling to decrease the photosynthetic area and slowing mechanical harvesting. In most sugarcane production areas of the world, herbicide use (chemical control) is the most common way to control sugarcane weeds. Table 5 displays a non exhaustive list of the most common sugarcane weeds occurring in sugarcane fields and Table 6 displays the registered products used to control them.

\section{Sugarcane Diseases}

Most commercial sugarcane varieties are genetically resistant to most sugarcane diseases. In addition to genetic resistance, use of pathogen-free planting material is commonly used to avoid spreading of diseases. The Brazilian sugarcane industry does not usually control sugarcane diseases in commercial fields, but recently, coinciding with the first detection of the Orange rust (Puccinia kuehnii) in the country, the Agriculture Department has registered a product (azoxystrobin and ketoconazole) to control fungal disesases at sugarcane fields (Santos, 2008; Agrofit, 2010). Additionally, the Triazole fungicides triadimefon and triadimenol are registered to treat sugarcane stalks before planting to prevent smut contamination caused by Ustilago scitaminea (AGROFIT 2010). Sugarcane smut disease is also contolled by destroying contaminated plants in the field (roguing) when varieties having intermediate resistance to the pathogen are planted.

Table 7 displays a list of the most common sugarcane diseases in Brazil.

\section{Environmental Impacts}

Sugarcane's high efficiency in fixing $\mathrm{CO} 2$ into carbohydrates for conversion into fuel has awakened the world's interest in the crop. Emerging data indicates that sugarcane could be the best crop for the production of renewable energy, which could reduce some effects of global warming caused by the use of fossil fuels (Buckeridge, 2007). The impact of sugarcane on the environment might be reduced by adopting environmentally friendly agricultural practices such as the elimination of burning before harvest, modifying other practices for a reduction in diesel-driven transportation and a reduction in the use of oil-based fertilizers (Ometto et al., 2005).

Brazil's land area currently occupied by sugarcane is mainly the result of the large expansion of the sugarcane industry that occurred in the 1970s, when the Pró-Álcool (pro-ethanol) program was created. During this period, sugarcane expansion occurred in areas that were originally covered with Atlantic Rain Forest, but which were already being used for pastures and annual crops. The current rapid expansion of sugarcane into new areas that have never been used to grow the crop raises questions about sustainability, particularly in those areas of the cerrado biome that are already threatened by the expansion of other crops (Rodrigues and Ortiz, 2006). This recent concern about the potential environmental impacts of crops has encouraged government agencies to promote studies to establish zones for planting sugarcane and to regulate how expansion will take place to avoid expansion into protected areas. This zoning proposal was recently approved and will allow the Brazilian Government to use Climatic Risk Zoning as a tool for the establishment of a sustainable sugarcane agribusiness in the country (Embrapa, 2009).

Hitorically, the sugarcane has been burned prior to harvest as a means to facilitate and thus reduce the costs for harvest and hauling of cane, whether harvested by hand or by machine. In addition, burning of the crop generally increased recovery of the sucrose contained in the plant. However, in the process of burning, carbon 
Table 4 Insects and nematodes there are most relevant to sugarcane agrosystem in Brazil

\begin{tabular}{|c|c|c|}
\hline Specie & Order & Common name english (Portuguese) \\
\hline \multicolumn{3}{|l|}{ Leaf/shoot apex/stalk pests } \\
\hline Diatraea saccharalis (Fabricius, 1794) & Lepidoptera & Sugarcane borer (Broca da cana-de-açúcar) \\
\hline Diatraea flavipennella (Box, 1931) & Lepidoptera & Sugarcane borer (Broca da cana-de-açúcar) \\
\hline Mocis latipes (Guenée, 1852) & Lepidoptera & Striped grassworm (Curuquerê-dos-capinzais) \\
\hline Spodoptera frugiperda (J. E. Smith, 1797) & Lepidoptera & Fall armyworm (Lagarta-do-cartucho) \\
\hline Mahanarva posticata (Stal, 1855) & Hemiptera & Spittlebug (Cigarrinha da folha) \\
\hline Elasmopalpus lignosellus (Zeller, 1848) & Hemiptera & Lesser cornstalk borer (Lagarta elasmo) \\
\hline Aclerda campinensis (Hempel, 1934) & Hemiptera & Sugarcane mealybug (Cochonilha parda) \\
\hline Saccharicoccus sacchari (Cockerell, 1895) & Hemiptera & Pink sugarcane mealybug (Cochonilha rosada) \\
\hline Melanaphis sacchari (Zehnter, 1897) & Hemiptera & Sugarcane aphid (Pulgão) \\
\hline Rhopalosiphum maidis (Fitch, 1856) & Hemiptera & Corn leaf aphid (Pulgão) \\
\hline Atta bisphaerica (Forel, 1908) & Hymenoptera & Giant leaf-cutting ant (Saúva mata-pasto) \\
\hline Atta capiguara (Gonçalves, 1944) & Hymenoptera & Grass cutting ant (Saúva parda) \\
\hline Metamasius hemipterus (Linnaeus, 1765) & Coleoptera & West Indian sugarcane weevil (Besouro-rajado-da-cana) \\
\hline Tomaspis furcata (Germar, 1821) & Hemiptera & Spittlebug (Cigarrinha-das-pastagens) \\
\hline \multicolumn{3}{|l|}{ Stool pests } \\
\hline Mahanarva fimbriolata (Stal, 1854) & Hemiptera & Root froghopper (Cigarrinha da raíz) \\
\hline Telchin licus (Drury, 1773) & Lepidoptera & Giant sugarcane borer (Broca gigante) \\
\hline Hyponeuma taltula (Schaus, 1904) & Lepidoptera & Borer (Broca peluda) \\
\hline \multicolumn{3}{|l|}{ Underground pests } \\
\hline Heterotermes tenuis (Hagen, 1858) & Isoptera & Termite (Cupim) \\
\hline Heterotermes longipes (Snyder, 1924) & Isoptera & Termite (Cupim) \\
\hline Procornitermes triacifer (Silvestri, 1901) & Isoptera & Termite (Cupim) \\
\hline Neocapritermes opacus (Hagen, 1858) & Isoptera & Termite (Cupim) \\
\hline Neocapritermes parvus (Silvestri, 1901) & Isoptera & Termite (Cupim) \\
\hline Syntermes molestus (Burmeister, 1839) & Isoptera & Termite (Cupim) \\
\hline Cornitermes spp. & Isoptera & Termite (Cupim) \\
\hline Rhynchotermes spp. & Isoptera & Termite (Cupim) \\
\hline Migdolus fryanus (Westwood, 1863) & Coleoptera & Migdolus beetle (migdolus) \\
\hline Sphenophorus levis (Vaurie, 1978) & Coleoptera & Sugarcane weevil (Bicudo-da-cana) \\
\hline Euetheola humilis (Burmeister, 1847) & Coleoptera & Sugarcane beetle (Pão-de-galinha) \\
\hline Ligyrus bituberculatus (Beauvois, 1805) & Coleoptera & Banana beetle (Pão-de-galinha) \\
\hline Stenocrates laborator (Fabricius., 1775) & Coleoptera & Scarab beetle (Pão-de-galinha) \\
\hline Cyclocephala spp. & Coleoptera & Masked chafers (Besouro) \\
\hline \multicolumn{3}{|l|}{ Parasitoids } \\
\hline Cotesia flavipes (Cameron, 1891) & Hymenoptera & Larval parasitoid (Cotesia) \\
\hline Trichogramma galloi (Zucchi, 1988) & Hymenoptera & Egg parasitoid (Tricograma) \\
\hline Lydella minense (Townsend, 1927) & Diptera & Larval parasitoid (Mosca parasitóide) \\
\hline Billaea claripalpis (Wulp, 1896) & Diptera & Larval parasitoid (Mosca parasitóide) \\
\hline \multicolumn{3}{|l|}{ Predators } \\
\hline Solenopsis saevissima (F. Smith, 1855) & Hymenoptera & Fire ant (Formiga lava-pé) \\
\hline Crematogaster sp. & Hymenoptera & Ant (Formiga) \\
\hline Dorymyrmex sp. & Hymenoptera & Ant (Formiga) \\
\hline Pheidole sp. & Hymenoptera & Ant (Formiga) \\
\hline Doru lineare (Eschscholtz, 1822) & Dermaptera & Linear earwig (Tesourinha) \\
\hline Cycloneda sanguinea (Linnaeus, 1763) & Coleoptera & Ladybird (Joaninha) \\
\hline \multicolumn{3}{|l|}{ Other associated insects } \\
\hline Apis mellifera (Linnaeus, 1758) & Hymenoptera & Honeybee (Abelha) \\
\hline
\end{tabular}


Table 4 (continued)

\begin{tabular}{lll}
\hline Specie & Order & Common name english (Portuguese) \\
\hline Nematodes & & \\
Meloidogyne incognita (Kofoid and White, 1919) & Tylenchida & Root knot nematode (Nematóide das galhas) \\
Meloidogyne javanica (Treub, 1885) & Tylenchida & Root knot nematode (Nematóide das galhas) \\
Pratylenchus zeae (Graham, 1951) & Pratylenchidae & Dagger nematode (Nematóide-das-lesões) \\
Pratylenchus brachyurus (Godfrey 1929) & Pratylenchidae & Dagger nematode (Nematóide-das-lesões) \\
Helicotylenchus dihystera (Cobb, 1893) & Tylenchida & Spiral nematode (Nematóide-espiralado) \\
\hline
\end{tabular}

dioxide and other greenhouse gases, and soot or ash are released (Cançado et al., 2006). Brazilian law No. 11.241 (Sept. 19, 2002) in São Paulo State established a goal for the gradual elimination of sugarcane burning and associated measures by 2021 , with all harvesting being entirely mechanized on non-burned cane by 2031. On June 4, 2007 in anticipation of this law, UNICA (União da Indústria de Cana-de-açúcar) which is the Brazilian Sugarcane Industry Association representing the sugar, ethanol and bioelectricity producing industry of the State of São Paulo, and the state government signed the Protocolo Agroambiental do Setor Sucroalcooleiro [Sugar and Alcohol Industry Agro-Environmental Protocol]. This protocol established several environmental principles and technical guidelines to be observed by the sugarcane industry. Perhaps the most important guidelines are those addressing the anticipation of the legal deadline for the end of sugarcane harvesting within 14 years.

Table 5 List of common weeds occurring in Brazilian sugarcane fields. Source: Azania et al. (2008)

\begin{tabular}{|c|c|c|}
\hline Species & Family & Common name english (Portuguese) \\
\hline \multicolumn{3}{|l|}{ Annual } \\
\hline Acanthospermum australe (Loefl.) Kuntze & Asteraceae & Paraguayan burr (Carrapichinho) \\
\hline Acanthospermum hispidum DC. & Asteraceae & Bristly starburr (Carrapicho de carneiro) \\
\hline Ageratum conyzoides (L.) L. & Asteraceae & Billygoat-weed (Mentrasto/Ageratum) \\
\hline Alternanthera ficoidea (L.) Sm. & Amaranthaceae & Sanguinaria (Apaga-fogo) \\
\hline Amaranthus spp. & Amaranthaceae & Pigweed (Caruru) \\
\hline Bidens pilosa $\mathrm{L}$. & Asteraceae & Hairy beggarticks (Picão-preto) \\
\hline Brachiaria plantaginea (Link) Hitchc. & Poaceae & Signalgrass (Capim marmelada) \\
\hline Cenchrus echinatus L. & Poaceae & Southern sandbur (Capim carrapicho) \\
\hline Commelina spp. & Commelinaceae & Dayflower (Trapoeraba) \\
\hline Croton lobatus L. & Euphorbiaceae & Lobed croton (Cróton) \\
\hline Digitaria horizontalis Willd. & Poaceae & Jamaican Crabgrass (Capim colchão) \\
\hline Digitaria insularis (L.) Mez ex Ekman & Poaceae & Sourgrass (Capim-amargoso) \\
\hline Eleusine indica (L.) Gaertn. & Poaceae & Indian goosegrass (Capim pé-de-galinha) \\
\hline Emilia sonchifolia (L.) DC. & Asteraceae & Lilac tasselflower (Falsa-serralha) \\
\hline Euphorbia heterophylla L. & Euphorbiaceae & Mexican fireplant (Leiteiro) \\
\hline Ipomea spp. & Convolvulaceae & Morning glories (Cordas-de-viola) \\
\hline Portulaca oleracea L. & Portulacaceae & Little hogweed (Beldroega) \\
\hline Richardia brasiliensisGomes & Rubiaceae & Tropical Mexican clover (Poaia branca) \\
\hline Rottboellia exaltata (L.) L.f. & Poaceae & Ichtgrass (Capim-camalote) \\
\hline Sonchus oleraceus L. & Asteraceae & Common sowthistle (Serralha) \\
\hline \multicolumn{3}{|l|}{ Perennial } \\
\hline Brachiaria decumbensStapf & Poaceae & Spreading liverssed grass (Capim-braquiária) \\
\hline Brachiaria mutica (Forssk.) Stapf & Poaceae & Para grass (Capim-braquiária) \\
\hline Cynodon dactylon (L.) Pers. & Poaceae & Bermuda grass (Grama-seda) \\
\hline Cyperus rotundus (L.) & Cyperaceae & Nut Grass (Tiririca) \\
\hline Panicum maximum Jacq. & Poaceae & Guinegrass (Capim-colonião) \\
\hline Sida spp. & Malvaceae & Fanpetals (Guanxuma) \\
\hline Sorghum halepense (L.) Pers. & Poaceae & Johnson grass (Capim-massambará) \\
\hline
\end{tabular}


Table 6 Registered products to control weeds in sugarcane fields in Brazil. Source: AGROFIT (2010)

\begin{tabular}{|c|c|c|}
\hline Common name ${ }^{1}$ & Chemical group & Commercial name \\
\hline Acetochlor & chloroacetanilide & Fist EC, Surpass \\
\hline Alaclhor & chloroacetanilide & Alaclor + Atrazina SC Nortox, Alaclor Nortox, Boxer, Laço EC \\
\hline Ametryn & triazine & $\begin{array}{l}\text { Agritin SC, Ametrex } 500 \text { SC, Ametrina Agripec, Ametrina Anator } 50 \text { SC, Ametron, Ametron } \\
\text { SC, Bimetron, Gesapax } 500 \text { Ciba-Geisy, Herbipak WG, Herbipak } 500 \text { BR, Krismat WG, } \\
\text { Metrimex, Metrimex } 500 \text { SC, Simetrex SC, Sinerge EC, Stopper } 500 \text { SC, Topeze SC }\end{array}$ \\
\hline Amicarbazone & triazolinone & Dinamic \\
\hline Asulam & $\begin{array}{l}\text { Sulphanilyl } \\
\text { carbamate }\end{array}$ & Asulox 400 \\
\hline Atrazine & triazine & $\begin{array}{l}\text { Alaclor + Atrazina SC Nortox, Atrazina Nortox } 500 \text { SC, Atraxinax 500, Boxer, Genius WG, } \\
\text { Gesaprim GrDa, Gesaprim } 500 \text { Ciba-Geisy, Herbitrin } 500 \text { BR, Proof, Siptran } 500 \text { SC, Siptram } \\
800 \text { WP, Sprint }\end{array}$ \\
\hline Carfentrazone-ethyl & triazolone & Aurora, Aurora 400 EC, Quicksilver 400 EC \\
\hline Clomazone & isoxazolidinone & $\begin{array}{l}\text { Clomanex } 500 \text { EC, Clomazone } 500 \text { EC FMC, Discover } 500 \text { WP, Escudo, Gamit, Gamit Star, } \\
\text { Gamit } 360 \text { CS, Magister, Ranger, Reator } 360 \text { CS, Sinerge SC }\end{array}$ \\
\hline Paraquat dichloride & bipyridilium & Gramocil, Gramoxone 200, Helmoxone, Paradox \\
\hline Diclosulam & $\begin{array}{l}\text { triazolopyrimidine } \\
\text { sulfonanilide }\end{array}$ & Coact \\
\hline Diuron & urea & $\begin{array}{l}\text { Advance, Agritin SC, Ametron, Ametron SC, Bimate SA, Bimetron, Cention SC, Confidence, } \\
\text { Dihex, Direx } 500 \text { SC, Diurex Agricur } 500 \text { SC, Diurex Agricur } 800 \text { SC, Diurex WG, } \\
\text { Diuromex, Diuron Fersol } 500 \text { SC, Diuron Milenia WG, Diuron Nortox, Diuron Nortox } 500 \\
\text { SC, Diuron } 500 \text { Agritec, Diuron } 500 \text { SC, Diuron } 500 \text { SC Milenia, Diuron } 80 \text { Volagro, Diuron } \\
80 \text { Volcano, Dizone, Fortex SC, Gramocil, Herburon WG, Herburon } 500 \text { BR, Hexaron, } \\
\text { Hexaron WG, Jump, Karmex, Karmex 800, Netun } 500 \text { SC, Netum } 800 \text { SC, Rancho, Scopus, } \\
\text { Soldier, Soligard, Velpar Max, Velpar-K, Velpar-K WG }\end{array}$ \\
\hline Ethoxysulfuron & sulfonylurea & Gladium \\
\hline Flazasulfuron & sulfonylurea & Katana \\
\hline Glyphosate & substituted glycine & $\begin{array}{l}\text { Direct, Fera, Gliato, Glifos, Glifos Concept, Glifos N, Glifos Plus, Glifosato Atanor, Glifosato } \\
\text { Atar 48, Glifosato Nortox, Glifosato Nortox WG, Glifosato Nufarm, Glifosato } 480 \text { Agripec, } \\
\text { Gliphogan 480, Glister, Gliz } 480 \text { SL, Glyox, Glyphotal, Icaro, Pilarsato, Polaris, Pretorian, } \\
\text { Radar, Rodeo, Ronat-A, Roundup Original, Roundup Transorb, Roundup WG, Rustler, } \\
\text { Samurai, Scuder, Stinger, Sumô, Trop }\end{array}$ \\
\hline $\begin{array}{l}\text { Glyphosate } \\
\text { isopropylamine } \\
\text { salt }\end{array}$ & substituted glycine & Glifosato Atanor 40, Gli-Up 480 SL, Gliz Plus, Glizmax, Sumô, Tupan \\
\hline Halosulfuron methyl & sulfonylurea & Sempra \\
\hline Hexazinone & triazinone & $\begin{array}{l}\text { Advance, Broker } 750 \text { WG, Confidence, Destaque, Dihex, Discover } 500 \text { WP, Dizone, Hexaron, } \\
\text { Hexaron WG, Hexazinona Nortox, Hexazinona Nortox } 250 \text { SL, Jump, Perform } 240 \text { SL, } \\
\text { Rancho, Ranger, Scopus, Soldier, Soligard, Style, Velpar Max, Velpar-K, Velpar-K WG }\end{array}$ \\
\hline Imazapic & Imidazolinone & Plateau \\
\hline Imazapyr & imidazolinone & Contain \\
\hline Iodosulfuron-methyl & sulfonylurea & Hussar \\
\hline Isoxaflutol & isoxazol & Provence $750 \mathrm{WG}$ \\
\hline MCPA & aryloxyalkanoyl & Agritin SC \\
\hline Metribuzin & triazinone & Lexone SC, Sencor BR, Sencor WG, Sencor 480, Sencor 70 WG, Soccer SC \\
\hline Metsulfuron-methyl & sulfonylurea & Ally, Wolf \\
\hline MSMA & organoarsenic & $\begin{array}{l}\text { Ancosar 720, Ansar 720, Daconate 480, Dessecan, Fortex SC, MSMA Sanachem } 720 \text { SL, } \\
\text { MSMA 720, MSMA } 720 \text { Volagro, Volcane }\end{array}$ \\
\hline Oxadiazon & oxadiazolone & Ronstar $250 \mathrm{BR}$ \\
\hline Oxifluorfen & diphenyl ether & Galigan 240 EC, Goal BR \\
\hline Pendimethalin & dinitroaniline & Herbadox, Herbadox 400 EC \\
\hline Picloram & $\begin{array}{l}\text { pyridinecarboxylic } \\
\text { acid }\end{array}$ & Dontor \\
\hline Simazine & triazine & Simetrex SC, Topeze SC \\
\hline S-metolachlor & chloroacetanilide & Dual Gold \\
\hline
\end{tabular}


Table 6 (continued)

\begin{tabular}{|c|c|c|}
\hline Common name ${ }^{1}$ & Chemical group & Commercial name \\
\hline Sulfentrazone & triazolone & Boral 500 SC, Explorer 500 SC \\
\hline $\begin{array}{l}\text { Sulfometuron- } \\
\text { methyl }{ }^{2}\end{array}$ & sulfonylurea & Curavial \\
\hline Tebuthiuron & urea & Aval, Aval 800, Bimate SA, Butiron, Combine 500 SC, Lava, Lava 800 \\
\hline Thiazopyr & $\begin{array}{l}\text { pyridinecarboxylic } \\
\text { acid }\end{array}$ & Visor $240 \mathrm{EC}$ \\
\hline $\begin{array}{l}\text { Trifloxysulfuron } \\
\text { sodium }\end{array}$ & sulfonylurea & Envoke, Krismat WG \\
\hline Trifluralin & dinitroaniline & Novolate, Premerlin 600 EC, Trifuralina Nortox Gold \\
\hline 2,4-D & aryloxyalkanoyl & $\begin{array}{l}\text { Aminamar, Aminol 806, Bratt, Brion, Capri, Dez, DMA } 806 \text { BR, Dontor, Grant, Herbi D-480, } \\
\text { Navajo, Tento } 867 \text { SL, U } 46 \text { BR, U } 46 \text { D-Fluid 2,4-D, Weedar 806, 2,4D Agritec, 2,4-D } \\
\text { Amina 72, 2,4-D Fersol }\end{array}$ \\
\hline
\end{tabular}

\section{Potential Invasiveness}

Weediness of Commercial Hybrids and Related Species

As a result of continuous breeding and selection for agronomic traits of value, sugarcane has lost the competitiveness or invasiveness of the original species; modern cultivars have largely lost the ability to persist in non-agricultural habitats and only poorly perpetuate without human assistance (Holm et al., 1997; OGTR, 2008). Sugarcane hybrid cultivars do not possess true rhizomes or produce vigorous seedlings. It is possible to find leftover stools in cultivated areas, but there is no indication that these stools will perpetuate, and there is even less evidence that they have any invasive capacity. It is possible that if ratoons are not properly eradicated at the end of a cultivation cycle, they can regrow

Table 7 List of common diseases occurring at Brazilian sugarcane fields. Source: Dinardo-Miranda (2008a); Dinardo-Miranda (2008b); Almeida (2008)

\begin{tabular}{|c|c|c|}
\hline Species & Type & $\begin{array}{l}\text { Disease } \\
\text { English (Portuguese) name }\end{array}$ \\
\hline Puccinia melanocephala Syd. \& P. Syd. & Fungal & Rust (Ferrugem) \\
\hline Puccinia kuehnii (W. Krüger) E.J. Butler & Fungal & Rust (Ferrugem) \\
\hline Ustilago scitaminea Syd. & Fungal & Smut (Carvão) \\
\hline Mycovellosiella koepkei (W. Kruger) Deighton & Fungal & Yellow spot (Mancha amarela) \\
\hline Bipolaris sacchari (E.J. Butler) Shoemaker & Fungal & Eye spot (Mancha ocular) \\
\hline Cercospora longipes E. J. Butler & Fungal & Brown spot (Mancha parda) \\
\hline $\begin{array}{l}\text { Glomerella tucumanensis (Speg.) Arx \& E. Müll. } \\
\text { Anamorph: Colletotrichum falcatum Went }\end{array}$ & Fungal & Red rot (Podridão vermelha) \\
\hline $\begin{array}{l}\text { Gibberella fujikuroi (Sawada) Wollenw. } \\
\text { Anamorph: Fusarium moniliforme J. Sheld. }\end{array}$ & Fungal & Stem Rot (Podridão de Fusarium) \\
\hline $\begin{array}{l}\text { Gibberella subglutinans (E.T. Edwards) P.E. Nelson, } \\
\text { Toussoun \& Marasas } \\
\text { Anamorph: Fusarium subglutinans (Wollenw. \& Reinking) } \\
\text { P.E. Nelson, Toussoun \& Marasas }\end{array}$ & Fungal & Pokkah-boeng (Pokkah-boeng) \\
\hline $\begin{array}{l}\text { Thielaviopsis paradoxa (De Seynes) V. Hohny } \\
\text { Anamorph: Ceratocystis paradoxa (Dade) C. Moreau }\end{array}$ & Fungal & Pineapple disease (Podridão abacaxi) \\
\hline Leifsonia xyli supsp. xyli (Davis et al.) Evtushenko & Bacterial & Ratoon stunting disease (Raquitismo da soqueira) \\
\hline Xanthomonas albilineans (Ashby) Dowson & Bacterial & Leaf scald (Escaldadura das folhas) \\
\hline $\begin{array}{l}\text { Xanthomonas axonopodis pv. vasculorum (Cobb) Vauterin, } \\
\text { Hoste, Kersters \& Swings }\end{array}$ & Bacterial & Gumming disease (Gomose) \\
\hline $\begin{array}{l}\text { Acidovorax avenae subsp. avenae (Manns) Willens, Goor, } \\
\text { Thielemans, Gillis, Kersters e De Ley }\end{array}$ & Bacterial & Red stripe (Estria vermelha) \\
\hline Sugarcane mosaic virus (SCMV) & Virus & Mosaic (Mosaico) \\
\hline Sugarcane yellow leaf virus (SCYLV) & Virus & Yellow leaf (Amarelinho) \\
\hline Sugarcane bacilliform virus (SCBV) & Virus & Sugarcane bacilliform virus \\
\hline
\end{tabular}


and become volunteer plants in the next crop. However, since the ratoons do not possess the ability to spread, they remain as isolated stools in the new crop.

Some species from which modern sugarcane hybrids are derived are classified as weeds. S. spontaneum has an invasive potential because it produces rhizomes that contribute to natural vegetative propagation and enable the species to adapt to a great range of environmental conditions. S. spontaneum is classified as a noxious weed in the United States (USDA, 2008) and is considered a weed in many other countries (GCW, 2009). It is important to emphasize that the rhizomatous nature of $S$. spontaneum was not incorporated into modern sugarcane hybrids. S. arundinaceum (Syn: Erianthus arundinaceum) is also recorded as a weed in the United States and in some Asian countries (GCW, 2009). The other species of the Saccharum complex (S. robustum, $S$. sinensis and $S$. edule) that may have been involved in the evolution of sugarcane varieties have not been recorded as exhibiting weed potential (GCW, 2009). Among other genera of the Saccharum complex (Miscanthus, Narenga and Sclerostachia), only Miscanthus and Narenga represent species classified as having weed potential (GCW, 2009). Narenga porphyrochoma $(\mathrm{Syn}=$ Saccharum narenga) is cited as a weed in Vietnam (Koo et al., 2000 in GCW, 2009). The genus Miscanthus contains five species that have been reported as having weed potential in some parts of the world: $M$. floridulus ( $\mathrm{Syn}=M$. japonicus), $M$. nepalensis, M. purpurascens $(\mathrm{Syn}=$ Miscanthus sinensis Subsp. purpurascens), M. sacchariflorus and M. sinensis (GCW, 2009).

There are other Saccharum species, which are not involved in the origin of sugarcane hybrids, that have also been recorded as having weed potential in some parts of the world, including: S. angustifoulius, S. bengalense, S. florindum, S. procerum, S. ravenae and S. villosum (Syn= S. trinii) (GCW, 2009).

Weediness of Commercial Sugarcane Varieties and Their Related Species in Brazil

After more than five centuries of sugarcane cultivation in Brazil, there is no evidence that this crop presents any traits that favor persistence and invasibility and there is no evidence of dispersion outside of agricultural environments. Commercial propagation is vegetative, and seedlings from breeding programs lack vigor.

As stated previously, no species that were involved in the origin of sugarcane hybrids are native to Brazil, but some species of Saccharum did originate in this country. Among those species, only $S$. angustifolium and $S$ villosum are recorded as having some weed potential. $S$. angustifolium is listed as a weed in pastures in southern Brazil, where it originated. The plant is not consumed by cattle, thus allowing it to occupy areas that might otherwise be occupied by more desirable species. In addition, $S$. angustifolium is able to spread into abandoned land and roadsides (Kissmann 1997; Lorenzi, 2000). Unlike S. angustifolium, which seems to be restricted to southern Brazil, Saccharum villosum (Syn= Saccharum trinii) occurs throughout the country, but it is not recorded as having weed potential. However, this latter species has been recorded as an alien naturalized species in Mexico (Villaseñor and Espinosa-Garcia, 2004 in GCW, 2009).

There are no reports of the presence of Narenga species in Brazil, but there have been reports of the introduction of Miscanthus species into the country for their ornamental potential (Lorenzi and Sousa 2001; Bastos, 2008). Nothing is known about how these introduced species will behave in the Brazilian environment. Although some of them are already recorded as weeds in other countries, there have been no reports of their occurrence as weeds in Brazil (GCW, 2009; Lorenzi, 2000).

\section{Persistence of Commercial Varieties in Agricultural Systems}

Unlike most crops, modern sugarcane varieties are propagated vegetatively, and seeds are not disseminated in agricultural areas. As a consequence, the sexual reproduction of sugarcane has been inadequately studied; most information related to this field has come from breeders. There have been virtually no studies on the fertility and longevity of seeds produced in commercial fields or on their germination responses to environmental variables. However, sugarcane breeders invest great effort to obtain and preserve germinability of seed produced in their breeding programs. Preliminary studies have shown that the optimal temperature for seed germination is $36^{\circ} \mathrm{C}$. Seed could also germinate well after 8 weeks of storage at $24^{\circ} \mathrm{C}$, indicating a possible dormancy characteristic (OlivaresVillegas et al., 2008).

In Brazil, sugarcane occasionally blooms in commercial fields and it produces seeds in the northern/ northeastern regions much more often than in midwestern/ southern regions. If these seeds fall onto the ground and encounter high humidity conditions, they may germinate to produce new plants. However, due to heavy competition with the existing sugarcane, weeds, the actions of pathogenic agents and predators in the non- cultivated areas, or herbicides and weeding in the cultivated areas, these volunteer plants do not survive for long periods of time. If ratoons are not properly eradicated, they can regrow in the next crop, behaving as a source of volunteer plants, but there has been no reported case of volunteers spreading throughout the field. However, 
to avoid the presence of volunteer plants, the application of herbicides during the eradication phase is highly recommended.

\section{Impacts on Human and Animal Health}

Sugarcane has a long history of safe use as a food for humans and animal feed. It is commercially cultivated for use as a source of sucrose. Its byproducts are commonly used as components of ruminant feeds: bagasse as a fiber source and molasses as an energy source. The syrup is also used as a sugar substitute in food.

The large-scale use of sugarcane as a source of fuel ethanol began with the implementation of the Pró-Álcool program in the 1970s. Industrial processing of sugarcane to obtain sugar and ethanol involve several phases (heating, flocculation, filtration, fermentation, distillation), which produces crystallized sugar and/or ethanol. These products are practically free of any contamination by other organic molecules (Leme Junior and Borges, 1965).

Sucrose is a molecule with an extensive history of human consumption. It is consumed as a sweetener and energy source and is classified as non-toxic to humans, with an $\mathrm{LD}_{50}$ in rats of $29.7 \mathrm{~g} / \mathrm{kg}$ of body weight (SigmaAldrich, 2007a). Although consumption of standard doses of sucrose has always been considered safe, excessive oral consumption of sucrose may cause gastrointestinal problems. While there is no evidence of a direct correlation between sucrose consumption and toxicity, many studies suggest that average consumption should be reduced due to a possible association with health problems such as cardiovascular diseases, type II diabetes, obesity and hypertension (Howard and Wylie-Rosett, 2002). In addition, the relationship between sucrose consumption and an increased risk of developing dental cavities has been established (Rugg-Gunn and Murray, 1983; Sreebny, 1982).

The consumption of ethanol in alcoholic beverages may also be harmful to human health. The $\mathrm{LD}_{50}$ in rats is $7 \mathrm{~g} / \mathrm{kg}$ of body weight (Sigma-Aldrich, 2007b). Ethanol is considered toxic to humans if it is consumed in high doses and inhalation for a long period of time may provoke coughing, respiratory insufficiency, dizziness and intoxication. Eye contact may cause severe irritation. The excessive consumption of alcoholic beverages causes damage to practically all organs, particularly the liver, kidneys and central nervous system. The acute effects of ethanol ingestion range from dizziness and intoxication to alcoholic coma and death. Excessive consumption of alcoholic beverages during pregnancy is associated with the induction of fetal alcohol syndrome in the offspring and the occurrence of low weight and asphyxia at birth, among other problems (Sigma-Aldrich, 2007b).
Sugarcane pollen, like that of many other plants, has allergenic potential and may cause immunological hypersensitivity in humans who come into contact with it through the respiratory tract. In an allergy skin test conducted in India by Chakraborty et al. (2001), land workers having respiratory disorders showed enhanced reactivity to the pollen of plants of different botanical families, including sugarcane and rice.

\section{Industrial Processing (Sugar, Ethanol, Vinasse, Filtercake and Biomass)}

The objective of industrial sugarcane processing is to obtain highly purified sugar and ethanol. The process involves pressing of the sugarcane to obtain juice, which goes through several phases of purification and concentration, followed by crystallization (in the case of sugar production) or fermentation and distillation (in the case of ethanol production). Sucrose and ethanol, which are pure and chemically defined substances, are obtained at the conclusion of both processes. The byproducts are vinasse (also called vinhoto) and bagasse (biomass). Figure 8 illustrates the phases involved in the industrial production of sugarcane products and byproducts.

Ethanol Ethyl alcohol, or ethanol, is a flammable liquid substance that is obtained through the distillation of fermented sugars. The main substrate for ethanol production from sugarcane is the sucrose contained in the juice. Hydrated ethanol, the final product of the process, is a binary mixture of ethanol and water, with an ethanol content of approximately $96^{\circ}$ GL $\left(96^{\circ}\right.$ Gay-Lussac, 96\% ethanol $+4 \%$ water). This product may be used directly as transportation fuel or may be dehydrated, generating anhydrous ethanol. Anhydrous ethanol (99.5 $\mathrm{GL})$ is used in Brazil as a gasoline additive. According to Brazilian Law No. 10696/2003, the volume of anhydrous ethanol added to gasoline may vary from 20 to $25 \%$ (Copersucar, 2008).

Sugar The raw sugar obtained directly from sugarcane processing consists of $99.8 \%$ sucrose and $0.2 \%$ impurities $(0.04 \%$ humidity; $0.07 \%$ minerals; $0.07 \%$ inverted sugar; $0.02 \%$ insoluble material). Refined white sugar is obtained by dissolving raw sugar and removing the insoluble material and natural colorants through physical processes (Quast, 1986). After this additional purification step, the sucrose content of refined white sugar reaches $99.93 \%$ (Clarke, 1988).

In some countries of the European Union, Australia, Mexico, Canada, the United States and Japan, sugar produced from glyphosate and gluphosinate resistant, 
Sugarcane Industrial Processing

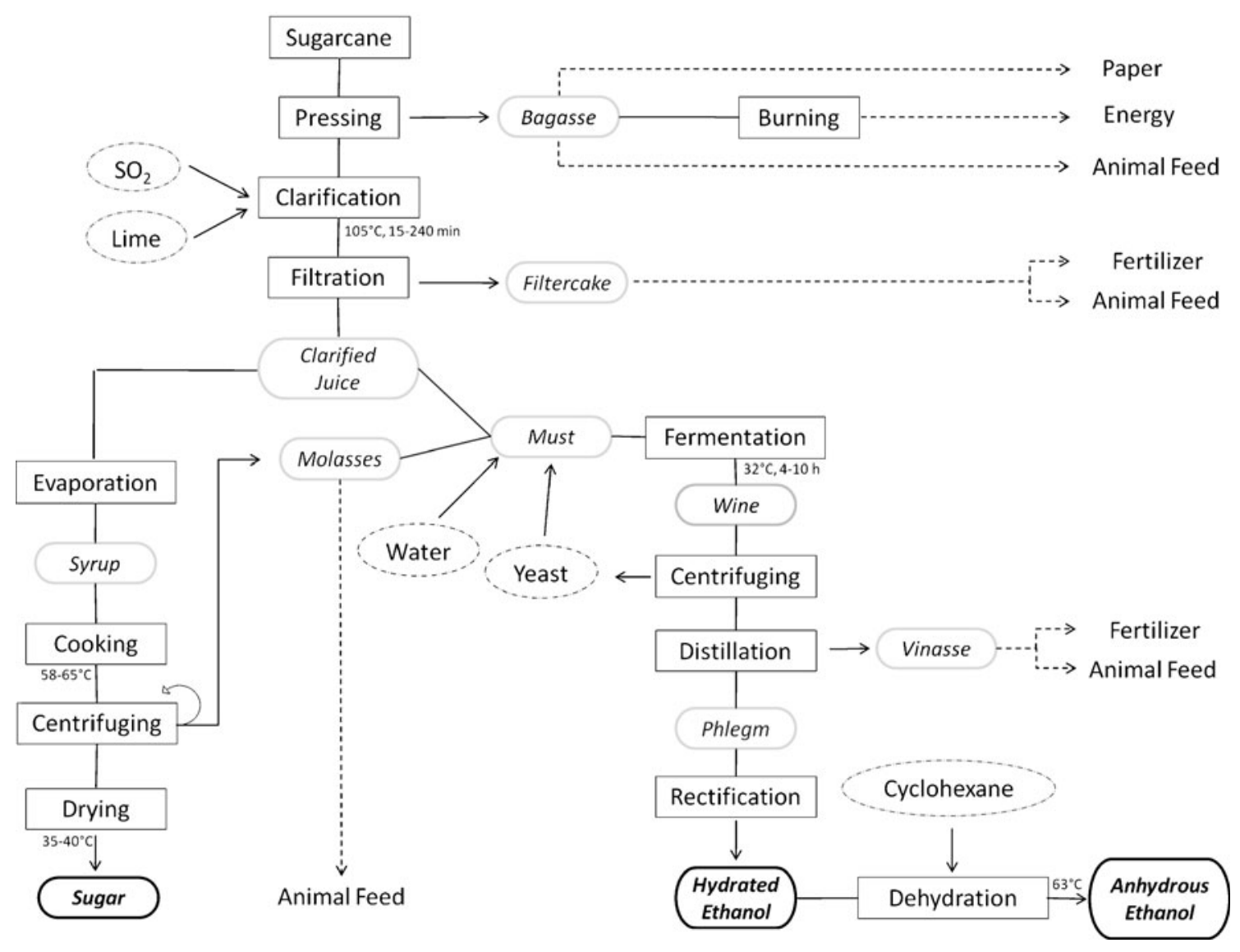

Fig. 8 Sugarcane industrial processing

genetically modified sugarbeets has already been approved for human consumption. In those cases, the composition analysis of the sugarbeet roots detected negligible amount of total protein and the analysis of refined sugar were not able to detect heterologous protein at the final product (CERA 2008).

Vinasse Vinasse is a residue of industrial sugarcane processing that consists of suspended solids and organic and mineral substances, mainly potassium (Almeida, 1952). Orlando Filho (1983) presented options for the use of vinasse that include: protein production through anaerobic fermentation, methane gas production, use in the formulation of animal feed (following treatment to bring the concentration to $60^{\circ}$ Brix), and as fertilizer on fields. Despite the potential diversity of uses, vinasse is almost solely used in Brazil as a fertilizer in fields surrounding ethanol-producing mills.

Filter cake Filter cake is a byproduct of industrial sugarcane processing that is obtained from the rotation filters after residual sucrose is extracted from the sugar production leftover (sludge). Filter cake composition is variable, but in general, the residue is rich in minerals (nitrogen, phosphorus, potassium, calcium, magnesium and sulfur) and organic matter, mainly proteins and lipids. This residue is commonly used as a fertilizer or in animal feed (Nardin, 2007; Diaz et al., 1998).

Biomass The bagasse obtained after sugarcane pressing consists of lignocellulosic biomass. The volume of bagasse obtained ranges between $240 \mathrm{~kg}$ and $280 \mathrm{~kg}$ per ton of sugarcane. In the mills, this byproduct of sugarcane processing is burned to generate energy (Copersucar, 2008). Currently, this process is so efficient that mills generate excess electric energy that is added to the grid, providing electrical energy to nearby cities, especially during the dry season, when hydroelectric plants have difficulty in operating at full capacity due to the low water levels in rivers. Bagasse may also be used as a raw material for ethanol production through acid or enzymatic hydrolysis, where cellulose and hemicellulose fractions can be converted into hexoses and pentoses. After a purification process, the mixture can be fermented to produce ethanol. However, this technology is still under development, and its economic feasibility has yet to be proven. 


\section{Cachaça (Sugarcane Spirit)}

In Brazil, cachaça (or aguardente) production started during the colonial period, shortly after sugarcane was introduced into the Capitania de São Vicente in the 16th century and the first sugar mill was installed in this region (Lima, 1992). Cachaça production units have different names depending on the scale of production and the region in which they are produced; industrial cachaças are produced in distilleries; artisanal (or boutique) cachaças that are created in northeastern Brazil are produced in engenhos, a holdover from the colonial period; and artisanal cachaças that are created in southern and southeastern Brazil are produced in alambiques, which is the name of the equipment where distillation is conducted (SEBRAE, 2005).

Cachaça results from the distillation of fermented sugarcane juice; it has ethanol content between $38 \%$ and $54 \%$ by volume at $20^{\circ} \mathrm{C}$. According to a survey conducted by Martinelli et al. (2000), cachaça, with an annual consumption of seven liters per capta, is the most popular alcoholic beverage in the country after beer (ABRABE, 2008). Cachaça production is estimated at 1.3 billion liters, which essentially represents the internal market because exports represent less than $1 \%$ of total production. It is estimated that there are 30,000 cachaça production units throughout the country. The activity generates annual revenues of US\$ 500 million and approximately 400,000 direct and indirect jobs (SEBRAE, 2005).

\section{Artisanal Processing (Rapadura, Muscovado Sugar and Sugarcane Syrup)}

Rapadura, muscovado sugar, and sugarcane syrup are the main products of the artisanal sugarcane production system. These speciality products are produced on small farms that are characterized by their low technology levels and intensive use of labor. Since there is little boutique market integration, these products are sold in local markets, and their processing is simplified, as shown in Fig. 9.

Rapadura (Jaggery) Rapadura is the Portuguese word for jaggery, a concentrated product of sugarcane juice without the separation of molasses from the crystals whose color can vary from golden to dark brown. It is a
Fig. 9 Flow chart of artisanal sugarcane processing
Sugarcane Artisanal Processing

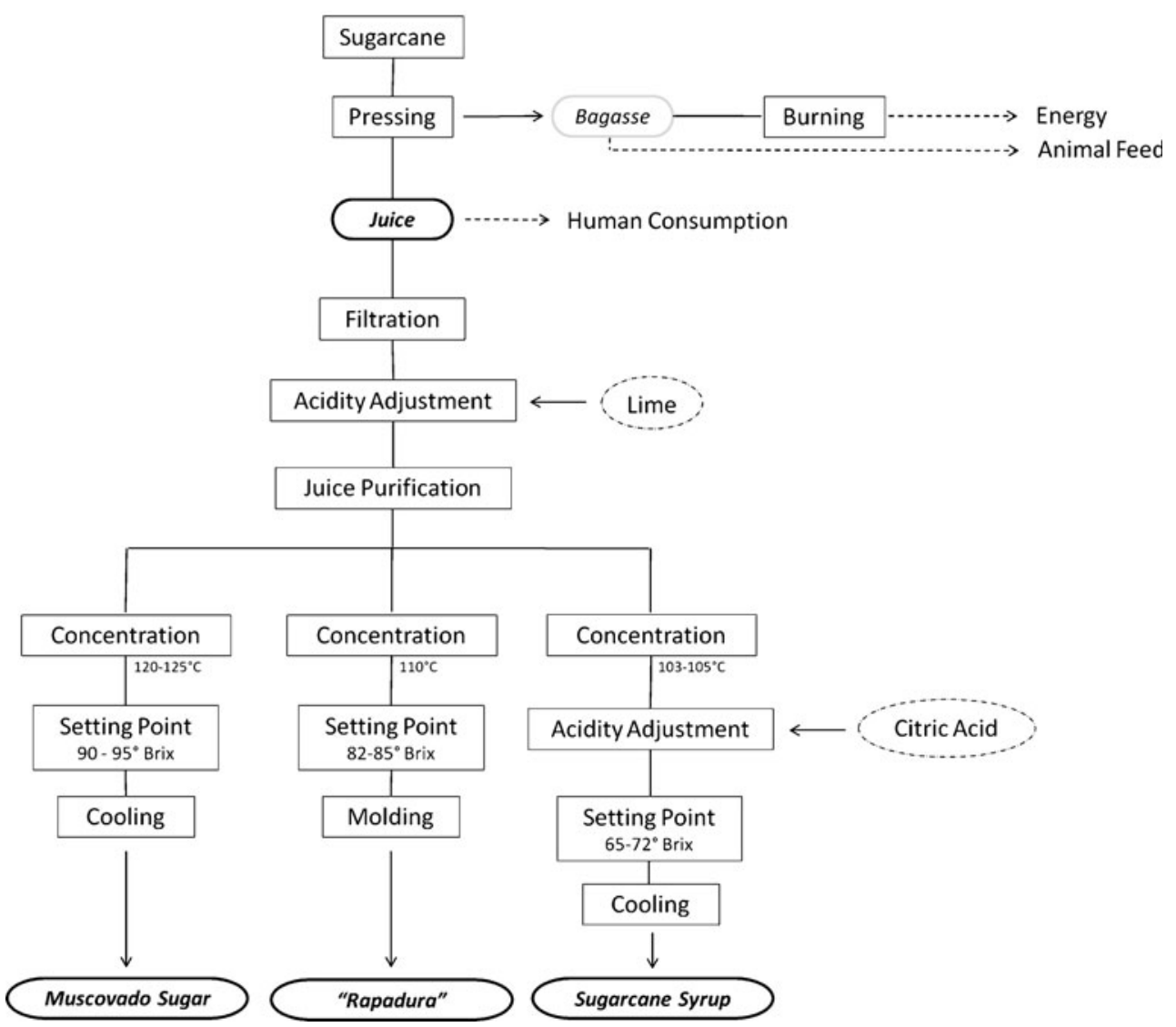


whole, unrefined sweetener that can be used in the same way as sugar with the additional flavor of molasses. The consumption of this product is concentrated in the rural areas of Brazil, mostly in the northeastern region where it is considered part of the cultural identity of the northeastern population (Coutinho, 2003). Data collected by FAO (Borray, 1997) showed that jaggery is produced in approximately 30 countries. India is the largest producer, as it is responsible for $67 \%$ of the world production; Colombia is the second largest producer, with the highest consumption per capita (32 kg/per capita/year). Brazil ranks seventh among the world's major jaggery producers and has a per capita consumption of $1.4 \mathrm{~kg} / \mathrm{year}$ (SEBRAE, 2005).

Muscovado Sugar Muscovado sugar production is similar to that of jaggery but with a process to achieve higher concentrations of soluble solids (Fig. 9) (Cesar et al., 2003). Industrial production of white sugar in combination with consumers' rejection of its dark color has caused muscovado sugar to nearly disappear. Thus, the muscovado sugar market has shrunk with a threat to the continuity of its production. Recently, however, muscovado sugar has been rediscovered by consumers seeking more "natural" products.

In poorer Brazilian regions, muscovado sugar and jaggery play important roles in children's diets because they provide excellent sources of low-cost energy in addition they contain an impressive level of minerals and proteins (calculated in $\mathrm{mg}$ per $100 \mathrm{~g}$ of product): potassium $(60-400)$, calcium $(50-350)$, magnesium (30-80), phosphorus (30-100), sodium (30-80), iron (2-10), manganese (1-5), zinc (1-4), and proteins (280). The vitamin content is not significant, snce vitamins are destroyed by heat (Chaves et al., 2003).

Sugarcane Syrup Sugarcane syrup, known in the northeast as "mel de engenho," is syrup produced through the concentration of sugarcane juice. It is also called "liquid rapadura" due to the similarity of these substances (Fig. 9). In general, rapadura and sugarcane syrup are processed in the same production unit (SEBRAE, 2005). It is an excellent source of energy and minerals, and because of its high iron level, it is considered an anti-anemic product. It has many uses in human diets depending on the region of Brazil in which it is being used (Chaves et al., 2003).

\section{Use of Sugarcane in Natura}

Unprocessed sugarcane is used as human food and animal feed. As a food item, sugarcane may be consumed in natura or as juice (garapa). In natura consumption is common in Brazilian rural areas, but juice consumption is much more common. Sugarcane juice is a nutritious energy drink that is very popular in Brazil where it is consumed by people of all ages and social strata, especially during the summer. The juice is extracted in electric or manual presses, sieved and served with ice, either pure or mixed with fruit juice (Lubatti, 1999; Soccol et al., 1990; Oliveira, 2007). Because this is an almost entirely informal activity, there is virtually no literature or reliable statistics on the sugarcane juice market (Oliveira, 2007). Studies conducted on samples collected from the product sold in cities of São Paulo State have shown poor hygienic conditions (Oliveira, 2007).

Sugarcane bagasse is the fibrous residue of juice extraction, consisting of water $(49 \%)$, fibers $(48.7 \%)$ and a small quantity of soluble solids (2.3\%) (Paturau, 1969). Bagasse fiber is a water-insoluble mixture that is mainly composed of cellulose, hemicellulose, pentosanes and lignin (Valsechi and Oliveira, 1964; Paturau, 1969; Delgado and Delgado, 1999; ICIDCA-GEPLACEA-PNUD 1990). Due to its high fiber content, sugarcane bagasse has been used as part of ruminant feed. Although its digestibility is low (approx. 25\%), digestibility can be increased to $65 \%$ through chemical, biological or thermomechanical treatments (Allen et al., 1997; Pate, 1982; de Medeiros and Machado, 1993; de la Cruz, 1990). In natura sugarcane is an economically feasible alternative to forage especially during the drought season, when pastures are not sufficient to feed herds (Embrapa Gado de Leite, 2008).

\section{Chemical Industry}

Biopolymers are polymeric-based materials that are structurally classified as polysaccharides, polyesters and polyamides. The basic raw material for production is a source of renewable carbon. The most important biopolymers are polylactate (PLA), polyhydroxyalkanoate (PHA), starch polymers (PA) and xantane (Xan). According to Pradella (2006), of all raw materials that are available for biopolymer production, sugarcane has one of the best profiles as a carbon source. The lignocellulosic fiber content of bagasse give sugarcane a unique competitive advantage compared to other carbon sources since bagasse may also be used to generate the energy used in biopolymer production.

\section{Biotechnological Development}

The sugarcane genome is among the most complex of cultivated crops. This complexity has hindered our understanding of sugarcane genetics and our ability to improve the crop using biotechnology tools (D'Hont et al., 2008). In the late 1990s, in situ hybridization studies helped clarify how the sugarcane genome is organized. A series of studies described part of its complexity and clearly established the 
ploidy level of the species, while revealing the coexistence of two distinct genome organization modes in modern varieties (D'Hont et al., 1996; D'Hont et al., 1998; Ha et al., 1999). Tomkins et al. (1999) built a bacterial artificial chromosome (BAC) library for the genome with over 100,000 clones, which facillitated beginning stages of physical mapping of sugarcane chromosomes and comparisons with other grasses. In the same period, several research groups started EST (expressed sequence tags) sequencing projects in South Africa (Carson and Botha, 2000), Australia (Casu et al., 2001) and Brazil (Vettore et al., 2001). Up to present, Brazilian sequencing project, called SUCEST, was the project with greater sugarcane EST sequence contribution, responsible for sequencing 238,000 ESTs from 26 different cDNA libraries.

Methods for the genetic transformation of sugarcane were reported decades ago. The first experiments in sugarcane genetic transformation were conducted in the late $1980 \mathrm{~s}$ (Chen et al., 1987) when a kanamycin-resistance gene was introduced into protoplasts through electroporation and polyethylene glycol treatment. Transformed plants were produced through particle bombardment (biolistics) of cell suspensions and embryogenic calli (Bower and Birch, 1992). Sun et al. (1993) obtained plants that were resistant to the herbicide amonium-gluphosinate through biolistics using the bar gene, which encodes phosphinothricin acetyltransferase. Gambley et al. (1994) bombarded meristematic tissues with microprojectiles and regenerated plants that expressed the luciferase gene. Later, Arencibia et al. (1995) reported a procedure for the stable transformation of meristematic tissues using electroporation. Gallo-Meagher and Irvine (1996) described the development of plants of the commercial cultivar NCo 310 containing the bar gene, which was transformed through biolistics.

Currently, many studies have demonstrated Agrobacterium-mediated and particle bombardment transformation of sugarcane with sufficient efficiency to produce commercial varieties (Bower and Birch, 1992; Birch and Maretzki 1993; Bower et al., 1996; Birch, 1997; Irvine and Mirkov, 1997; Joyce et al. 1998a, b; Arencibia et al., 1998; EnriquezObregon et al., 1998; Elliott et al. 1998; Moore, 1999; Nutt et al., 1999; Elliott et al. 1999; Manickavasagan et al., 2004). Additionaly, several genes of commercial interest have been introduced into sugarcane by genetic transformation, conferring herbicide tolerance, resistance to diseases and pests, tolerance to drought, increased sucrose content, and improvements in sugar quality and color (Falco et al., 2000; Braga et al., 2001; Braga et al., 2003; Zhang et al., 2006; Molinari et al., 2007). Sugarcane has also been transformed with genes with the intention of using the plant as a biofactory, producing high-value-added products such as bioplastics (Lakshmanan et al., 2005) and high-value isomers of sucrose (Wu and Birch, 2007).
In Brazil, the National Biosafety Commission (CTNBio) has approved more than 40 applications to conduct field trials of genetically modified sugarcane that contain genes conferring higher sucrose content, herbicide tolerance, insect resistance and drought tolerance. Field trials have also been conducted or are ongoing in South Africa, Australia and the United States. These trials will almost certainly result in biotechnology products. At present, however, transgenic sugarcane cultivars have not been commercially released in Brazil, or elsewhere in the world.

Open Access This article is distributed under the terms of the Creative Commons Attribution Noncommercial License which permits any noncommercial use, distribution, and reproduction in any medium, provided the original author(s) and source are credited.

\section{References}

ABRABE (2008) Associação Brasileira de Bebidas. http://www. abrabe.org.br. Cited 20 Mar 2008

AGROFIT (2010) Sistema de Agrotóxicos Fitossanitários. http:/ agrofit.agricultura.gov.br/agrofit_cons/principal_agrofit_cons. Cited 10 Jan 2011

Al-Janabi SM, Honeycutt RJ, Sobral BWS (1994) Phylogenetic analysis of organellar DNA sequences in the Andropogoneae: Saccharinae. Theor Appl Genet 88:933-944

Allen CJ, Mackay MJ, Aylward JH, Campbell JA (1997) New technologies for sugar milling and byproducts modification. In: Keating BA, Wilson JR (eds) Intensive Sugarcane Production: Meeting the Challenges Beyond 2000. CAB International, Wallingford, pp 267-285

Almaraj VA, Balasundaram N (2006) On the taxonomy of the members of 'Saccharum complex'. Genet Resour Crop Evol 53:35-41

Almeida Jr (1952) O problema da vinhaça em São Paulo. Piracicaba: ESALQ, Instituto Zimotécnico. Boletim n ${ }^{\circ}$ p 3.9

Almeida IMG (2008) Doenças causadas por bactérias. In: Dinardo-Miranda LL, Vasconcelos ACM, Landell MGA (eds) Cana-de-açúcar. Instituto Agronomico de Campinas, Campinas, $\mathrm{p} 882 \mathrm{p}$

Araújo MS, della Lucia TMC, Veiga CE, Nascimento IC (2004) Efeito da queima da palhada de cana-de-açúcar sobre comunidade de formicídeos. Ecol Aust 14:191-200

Araújo RA, Araújo MS, Gonring AHR, Guedes RNC (2005) Impacto da queima controlada da palhada da cana-de-açúcar sobre a comunidade de insetos locais. Neotrop Entomol 34:649-658

Arencibia A, Molina P, de la Riva G, Selman-Houssein G (1995) Production of transgenic sugarcane (Saccharum officinarum L.) plants by intact cell electroporation. Plant Cell Rep 14:305-309

Arencibia A, Carmona E, Tellez P, Chan MT, Yu SM, Trujillo L, Oramas P (1998) An efficient protocol for sugarcane (Saccharum spp.) transformation mediated by Agrobacterium tumefaciens. Transgenic Res 7:213-222

Azania CAM, Rolim JC, Azania AAPM (2008) Plantas Daninhas. In: Dinardo-Miranda LL, Vasconcelos ACM, Landell MGA (eds) Canade-açúcar. Instituto Agronomico de Campinas, Campinas, p 882p

Barbieri V, Maniero MA, Matsuoka S (1984) O florescimento da cana-de-açúcar e suas implicações no manejo agrícola. In: Congresso Nacional da STAB. São Paulo. Anais 3:273-276

Bastos G (2008) Rústicos e sofisticados. Natureza 242:40-45 
Bentham G (1883) Gramineae in Bentham \& hooker genera et species plantarum

Bento JMS, Vilella EF, della Lucia T, Leal WS, Novaretti WRT (1985) Migdolus: biologia, comportamento e controle. JMS Bento, Salvador, p 58p

Berding N (1981) Improved flowering and pollen fertility in sugarcane under increased night temperature. Crop Sci 21:863-867

Besse P, McIntyre CL, Berding N (1997) Characterisation of Erianthus sect. Ripidium and Saccharum germplasm (Andropogoneae-Saccharinae) using RFLP markers. Euphytica 93:283-292

Birch RG (1997) Transgenic sugarcane: opportunities and limitations. In: Keating BA, Wilson JR (eds) Intensive sugarcane production: meeting the challenge beyond 2000. CAB International, Wallingford 1: 125-140

Birch RG, Maretzki A (1993) Transformation of sugarcane. In: Bajaj YPS (Ed). Plant protoplast and genetic engeneering IV. Biotechnology in agriculture and forestry. Heidelberg: Springer-Verlag 23: $348-360$

Bonnett GD, Nowak E, Olivares-Villegas JJ, Berding N, Morgan T, Aitken KS (2008) Identifying the risks of transgene escape from sugarcane crops to related species, with particular reference to Saccharum spontaneum in Australia. Trop Plant Biol $1: 58-71$

Bor NL (1960) The grasses of Burma, Ceylon, India and Pakistan. Pergamon Press, London

Borray GAR (1997). La Panela en Colombia: un analisis de la Cadena Agroindustrial. In: Curso Internacional de Caña Panelera y su Agroindustria II. Barbosa. p 12

Bower R, Birch RG (1992) Transgenic sugarcane plants via microprojectile bombardment. Plant J 2:409-416

Bower R, Elliott AR, Potier BAM, Birch RG (1996) High-efficiency, microprojectile-mediated cotransformation of sugarcane, using visible or selectable markers. Mol Breed 2:239-249

Braga DPV, Arrigoni EDB, Burnquist WL, Silva-Filho MC, Ulian EC (2001) A new approach for control of Diatraea saccharalis (Lepidoptera: Crambidae) through the expression of an insecticidal CryIa(b) protein in transgenic sugarcane. International Society of Sugar Cane Technologists. Proceedings of the XXIV Congress, Brisbane, Australia, 17-21 September 2001. Volume 2:331-336

Braga DPV, Arrigoni EDB, Silva-Filho MC, Ulian EC (2003) Expression of the Cryl $\mathrm{Ab}$ protein in genetically modified sugarcane for the control of Diatraea saccharalis (Lepidoptera: Crambidae). J New Seeds 5:209-222

Bremer G (1961) Problems in breeding and cytology of sugarcane. Euphytica 10:59-78

Brett PGC (1951) Flowering and pollen fertility in relation to sugarcane breeding in Natal. Cong Proc Int Soc Sug Cane Technol 7:43-56

Brett PGC, Harding RL (1974) Artificial induction of flowering in Natal. Proc Int Soc Sug Cane Technol 15:55-66

Buckeridge M (2007) Seqüestro de carbono, cana-de-açúcar e o efeito Cinderela. Revista Com Ciência. http://www.comciencia.br/comcien cia/handler.php?section=8\&edicao $=23 \&$ id $=258$. Cited 10 Jan 2011

Cançado JED, Saldiva PHN, Pereira LAA, Lara LBLS, Artaxo P, Martinelli LA, Arbex MA, Zanobetti A, Braga ALF (2006) The impact of sugar cane-burning emissions on the respiratory system of children and the elderly. Environ Health Perspect 114 (5):725-729

Carporal FJM, Eggers L (2005) Poaceae na area do Centro de Pesquisas e Conservação da Natureza Pró-Mata, São Francisco de Paula, Rio Grande do Sul, Brasil. Iheringia Sér Bot 60(2):141-150

Carson DL, Botha FC (2000) Preliminary analysis of expressed sequence tags for sugarcane. Crop Sci 40:1769-1779

Casu R, Dimmock C, Thomas M, Bower N, Knight D, Grof C, McIntyre L, Jackson P, Jordan D, Whan V, Drenth J, Tao Y,
Manners J (2001) Genetic and expression profiling of sugarcane. Proc Int Soc Sug Cane Technol 24:626-627

CERA (2008) GM crop database. http://www.cera-gmc.org/? action=gm_crop_database. Cited 29 Sep 2010

Cesar MAA, Chaves JBP, Silva FC da, (2003) In: Silva FC da, Cesar MAA, Silva CAB da (eds) Pequenas Indústrias Rurais de Cana-deAçúcar: melado, rapadura e açúcar mascavo. Brasília. Embrapa Informação Tecnológica. 1: 53-82

Cesnik R, Miocque J (2004) Melhoramento da cana-de-açúcar. Brasília. Embrapa. p 307

Chakraborty P, Gupta-Bhattacharya S, Chowdhury I, Majumdar MR, Chanda S (2001) Differences in concentrations of allergenic pollens and spores at different heights on an agricultural farm in West Bengal India. Ann Agric Environ Med 8:123-130

Chaves JBP, Silva CAB da, Silva FC da, Cesar MAA (2003) In: Silva FC da, Cesar MAA, Silva CAB da (eds) Pequenas Indústrias Rurais de Cana-de-Açúcar: melado, rapadura e açúcar mascavo. Brasília. Embrapa Informação Tecnológica. 1: 11-20

Chen WH, Gartland KMA, Davey MR, Sotak R, Gartland JS, Mulligan BJ, Power JB, Cocking EC (1987) Transformation of sugarcane protoplasts by direct uptake of a selectable chimeric gene. Plant Cell Rep 6:297-301

Clarke MA (1988) Sugarcane processing: raw and refined sugar manufacture. In: Clarke MA, Godshall MA (eds) Chemistry and processing of sugarbeet and sugarcane. Elsevier Science Publishers BV, Amsterdam, pp 162-175

Clayton WD, Renvoize SA (1986) Genera graminum: grasses of the world. Kew Bull., Addit. Ser. 13

Clements HF, Awada M (1967) Experiments on the artificial induction of flowering in sugarcane. Proc Int Soc Sugcane Technol 12:795-812

Coleman RE (1969) Physiology of flowering in sugarcane. In: Proc Int Soc Sug Cane. 13: 992-1000

CONAB (2009) Acompanhamento da Safra Brasileira. http://www. conab.gov.br/conabweb/download/safra/3 levantamento2009 dez2009.pdf. Cited 27 Jan 2010

COPERSUCAR (1982) Nematóides parasitos da cana-de-açúcar e seu controle. In: Seminário de Tecnologia Agronômica, Piracicaba. São Paulo: Copersucar, 1982. pp 133-153

COPERSUCAR (2008) Academia do açúcar e do álcool. http://www. copersucar.com.br/institucional/por/academia/cana_acucar.asp. Cited 17 Mar 2008

Cordeiro GM, Pan YB, Henry RJ (2003) Sugarcane microsatellites for the assessment of genetic diversity in sugarcane germplasm. Plant Sci 165:181-189

Coutinho EP (2003) Implicações da modernização produtiva na qualidade da rapadura. In: Anais do XLI Congresso Brasileiro de Economia e Sociologia Rural. Juiz de Fora

D'Hont A (2005) Unraveling the genome structure of polyploids using FISH and GISH; examples of sugarcane and banana. Cytogenet Genome Res 109:27-33

D'Hont A, Rao PS, Feldmann P, Grivet L, Islam-Faridi N, Taylor P, Glaszmann JC (1995) Identification and characterization of sugarcane intergeneric hybrids, Saccharum officinarum x Erianthus arundinaceus, with molecular markers and DNA in situ hybridization. Theor Appl Genet 91:320-326

D'Hont A, Grivet L, Feldmann P, Rao S, Berding N, Glaszmann JC (1996) Characterisation of the double structure of modern sugarcane cultivars (Saccharum spp.) by molecular cytogenetics. Mol Gen Genet 250:405-413

D'Hont A, Ison D, Alix K, Roux C, Glaszmann JC (1998) Determination of basic chromosome numbers in the genus Saccharum by physical mapping of ribosomal RNA genes. Genome 41:221-225

D'Hont A, Paulet F, Glaszmann JC (2002) Oligoclonal interspecific origin of 'North Indian' and 'Chinese' sugarcanes. Chromos Res $10: 253-262$ 
D’Hont A, Souza GM, Menossi M, Vincentz M, van-Sluys MA, Glaszmann JC, Ulian E (2008) Sugarcane: a major source of sweetness, alcohol, and bio-energy. In: Moore PH, Ming R (eds) Plant genetics and genomics: crops and models. Springer New York. 1: 483-513

Daniels J, Daniels CA (1975) Geographical, historical and cultural aspects of the origin of the Indian Chinese sugarcanes $S$. barberi and $S$. sinense. Int Soc Sugar Cane Technol Sugargarcane Breed Newslett 36:4-23

Daniels J, Roach BT (1987) Taxonomy and evolution. In: Heinz DJ (ed) Sugarcane improvement through breeding. Amsterdam: Elsevier 1: 7-84

Darke R (1999) The color encyclopedia of ornamental grasses: sedges, rushes, restios, cat-tails and selected bamboos. Timber Press, Portland

de la Cruz HO (1990) Steam treated bagasse for fattening cattle. Effects of supplementation with Gliricidia sepium and urea molasses. Livestock Research Institute for Rural Development 2 (2). http://www.lrrd.org//rrd2/2/osorio.htm . Cited 10 Feb 2008

EMBRAPA Gado de Leite (2008) É hora de formar o canavial. http:// www.cnpgl.embrapa.br/nova/sala/noticias/jornaldoleite.php? id $=63$. Cited 07 Oct 2008

de Medeiros SR, Machado PF (1993) Effect of the replacement of steam treated sugarcane bagasse by milo upon performanceof finishing cattle. Livestock Research Institute for Rural Development 5 (2). http://www.lrrd.org/lrrd5/2/brazil2.htm . Cited $10 \mathrm{Feb}$ 2008

Delgado AA, Delgado AP (1999) Produção do açúcar mascavo rapadura e melaço. Piracicaba: Ed. Alves. p 154

Diaz JQ, Bizutti O, Melotti L, Lucci CS, Rodrigues PHM (1998) Digestibilidade (aparente) de rações com diferentes níveis de torta de filtro de usina açucareira com ovinos (Ovis aries L. Braz J Vet Res Anim Sci 35(1):51-54

Dillon SL, Shapter FM, Robert HJ, Cordeiro G, Izquierdo L, Lee SL (2007) Domestication to crop improvement: genetic resources for Sorghum and Saccharum (Andropogoneae). Ann Bot 5:975-989

Dinardo-Miranda LL (2008a) Pragas. In: Dinardo-Miranda LL, Vasconcelos ACM, Landell MGA (eds) Cana-de-açúcar. Instituto Agronomico de Campinas, Campinas, p 882

Dinardo-Miranda LL (2008b) Nematóides. In: Dinardo-Miranda LL, Vasconcelos ACM, Landell MGA (eds) Cana-de-açúcar. Instituto Agronomico de Campinas, Campinas, p 882

dos Anjos IA, Figueiredo PAM (2008) Aspéctos fitotécnicos do plantio. In: Dinardo-Miranda LL, Vasconcelos ACM, Landell MGA (eds) Cana-de-açúcar. Instituto Agronomico de Campinas, Campinas, $\mathrm{p} 882$

Dutt NL, Rao JT (1950) The present taxonomic position of Saccharum and its congeners. Proc 7th ISSCT, Brisbane, pp 287-293

Elliott AR, Campbell JA, Bretell RIS, Grof CPL (1998) Agrobacteriummediated transformation of sugarcane using GFP as a screenable marker. Aust J Plant Physiol 25:739-743

Elliott AR, Campbell JA, Dugdale B, Bretell RIS, Grof CPL (1999) Green fluorescent protein facilitates rapid in vivo detection of genetically transformed plant cells. Plant Cell Rep 18:707-714

EMBRAPA (2009) Zoenamento agroecológico da cana-de-açúcar. http://www.cnps.embrapa.br/zoneamento_cana_de_acucar/Zon Cana.pdf. Cited 30 Sep 2009

Enriquez-Obregon GA, Vazquez PRI, Prieto SDL, Riva-Gustavo ADL, Selman HG (1998) Herbicide resistant sugarcane (Saccharum officinarum L.) plants by Agrobacterium-mediated transformation. Planta 206:20-27

Ethirajan AS (1987) Sugarcane Hybridization Techniques. In: Copersucar International Sugarcane Breeding Workshop 1: 129-147
Falco MC, Neto AT, Ulian EC (2000) Transformation and expression of a gene for herbicide resistance in a Brazilian sugarcane. Plant Cell Rep 19:1188-1194

Figueira TRS, Serrano GCM, Arruda P (2008) Evolution of the genes encoding seed storage proteins in sugarcane and maize. Trop Plant Biol 1:108-119

Filgueiras TS, Lerina R (2001) Saccharum. In: Longhi-Wagner, HM (ed) Poacaeae, Flora Fanerogâmica do Estado de São Paulo, Fapesp-Hucitec, São Paulo. http://www.ibot.sp.gov.br/PES QUISA/florasp/florasp.htm. Cited 17 Mar 2008

FNP (2009) AGRIANUAL 2009 - Anuário da Agricultura Brasileira. São Paulo. p 497

Gallo-Meagher M, Irvine JE (1996) Herbicide-resistant sugarcane containing the bar gene. Crop Sci 36:1367-1374

Gambley RL, Bryant JD, Masel NP, Smith GR (1994) Cytokininenhanced regeneration of plants from microprojectile bombarded sugarcane meristematic tissue. Aust J Plant Physiol 21(5):603-612

GCW (2009) The global compendium of weeds. http://www.hear.org/ gcw. Cited 13 Aug 2009

Global Invasive Species Database (2008) http://www.issg.org/database/ species/search.asp?sts $=$ sss \&st $=$ sss \& fr $=1 \&$ sn $=\&$ rn $=$ bra zil\&hci $=-$ 1\&ei=-1\&lang=EN\&x=39\&y=11. Cited 07 Oct 2008

Gomes FP, Lima U (1964) A cana-de-açúcar no mundo. In: Malavolta et al (eds) Cultura e adubação da cana-de-açúcar. Instituto Brasileiro de Potassa, São Paulo, pp 11-26

Grassl CO (1946) Saccharum robustum and other wild relatives of noble sugarcanes. J Arnold Arbor 27:234-252

Grassl CO (1971) Taxonomy of Saccharum relatives: Sclerostachya. Narenga \& Erianthus. Proc ISSCT 14:240-248

Grassl CO (1980) Breeding Andropoganeae at the generic level for biomass. Sugarcane breeders Newsletter pp 41-57

Grivet L, Daniels C, Glaszmann JC, D'Hont A (2004) A review of recent molecular genetics evidence for sugarcane evolution and domestication. Ethnobotany Res Appl 2:9-17

Guimarães CT, Sills GR, Sobral BWS (1997) Comparative mapping of Andropogoneae: Saccharum L. (sugarcane) and its relation to sorghum and maize. Proc Natl Acad Sci 94:14261-14266

Ha S, Moore P, Heinz D, Kato S, Ohmido N, Fukui K (1999) Quantitative chromosome map of the polyploid Saccharum spontaneum by multifluorescence in situ hybridization and imagine methods. Plant Mol Biol 39:1165-1173

Hackel E (1883) Gramineae IV. Andropogoneae, Tristegineae. In: von Martius CFP (ed). Flora Brasiliensis 2(3):245-326, t. 59-74. F. Fieischer, Monachii et Lipsiae

Haines HH (1921). The Botany of Bihar and Orissa. London

Heinz DJ, Tew TL (1987) Hybridization procedures. In: Heinz DJ (ed) Sugarcane improvement through breeding. Elsevier, Amsterdam, pp 313-342

Hitchcock AS revised by Chase A (1951) Manual of the grasses of the United States. 2 ed. Washington, D.C., USDA, Misc. Publ. 200

Hogarth DM (1987) Genetics of sugarcane. In: Heinz DJ (ed) Sugarcane improvement through breeding. Elsevier, Amsterdam, pp 255-271

Holm L, Doll J, Holm E, Pancho J, Herberger J (1997) World seeds. Natural histories and distribution. John Wiley and sons Inc USA. p 129

Hooker JD (1896) Gramineae in Flora of British India. Vol VII

Howard BV, Wylie-Rosett J (2002) Sugar and cardiovascular disease. Circulation 106:523-535

ICIDCA-GEPLACEA-PNUD (1990) Manual de los derivados de la caña de azúcar. 2 ed. México. p 447

Instituto Horus (2008) Espécies Exóticas Invasoras: Fichas técnicas. http://www.institutohorus.org.br/inf fichas.htm. Cited 10 Jan 2011

Irvine JE (1999) Saccharum species as horticultural classes. Theor Appl Genet 98:186-194

Irvine JE, Mirkov TE (1997) The development of genetic transformation of sugarcane in Texas. Sugar J 60:25-29 
Jeswiet J (1925) Systematics of the genus Saccharum. Reports of the Expt. Station for Java sugar industry No. 12

Joyce PA, McQualter RB, Bernard MJ, Smith GR (1998a) Engineering for resistance to SCMV in sugarcane. Acta Hortic 461:385-391

Joyce PA, McQualter RB, Handley JA, Dale JL, Harding RM, Smith GR (1998b) Transgenic sugarcane resistant to sugarcane mosaic virus. In: Hogarth DM (ed) Proc Aust Soc Sugarcane Technol 20: 204-210

Julien MHR (1973) Physiology of flowering in Saccharum. I. Daylength control of floral initiation and development in $S$. spontaneum L. J Exp Bot 24:549-557

Kameyama C (2006) Checklist das plantas do Nordeste Brasileiro: angiospermas e gymnospermas. Associação Plantas do Nordeste. Ministério de Ciência e Tecnologia, Brasília, p 143

Kissmann, KG (1997) Plantas infestantes e nocivas. Tomo I, 2 ed. São Paulo: BASF. p 824

Koo SK, Chin YW, Kwon YW, Cung HA (2000) Common Weeds in Vietnam. Agriculture Publsihing House, Vietnam

Kuijper J (1915) DeGroei van Bladschijf, Bladscheede em Stengel van het suikerriet. Arch Suikerind Ned Indië 23:528-556

Lakshmanan P, Geijkes RJ, Aitken KS, Grof CLP, Bonnett GD, Smith GR (2005) Invited review: sugarcane biotechnology: the challenges and opportunities. Plant 41:354-363

Leme Junior J, Borges JM (1965). Açúcar de cana. Viçosa: UFV Imprensa Universitária. p 328

Lima UA (1992) Produção nacional de aguardentes e potencialidade dos mercados internos e externos. In: Mutton MJR, Mutton MA (eds) Aguardente de Cana - Produção e Qualidade. FUNEP Jaboticabal SP. pp 151-169

Lorenzi H (2000) Plantas daninhas do Brasil: terrestres, aquáticas, parasitas e tóxicas, 3 rdth edn. Instituto Plantarum, Nova Odessa, SP, p 608

Lorenzi H, Sousa HM (2001) Plantas ornamentais do Brasil: arbustivas, herváceas e trepadeiras, $3^{\text {rd }}$ ed. Instituo Plantarum, Nova Odessa, p 1087

Lubatti MRS (1999) Vendedor ambulante, profissão folclórica: pesquisa nas ruas, parques e jardins de São Paulo. Jangada Brasil, São Paulo 7: 1-2

Macedo N, Araújo JR (2000a) Efeitos da queima do canavial sobre insetos predadores. An Soc Entomol Bras 29:71-77

Macedo N, Araújo JR (2000b) Efeitos da queima do canavial sobre parasitóides de larvas e de ovos de Diatraea saccharalis (Fabr.) (Lepidoptera: Crambidae). Anais da Sociedade Entomológica do. Brasil 29:79-84

Manickavasagan M, Ganapathi A, Anbazhagan VR, Sudhakar B, Selvaraj N, Vasudevan A, Kasthuriregan S (2004) Agrobacterium-mediated genetic transformation and development of herbicide resistant sugarcane (Saccharum species hybrids) using axillary buds. Plant Cell Rep 23:134-143

Martin JP (1961) The anatomy of the sugar cane plant. In: Martin JP, Abbot EV, Hughes CG (eds) Sugarcane Diseases of the World. Elsevier Amsterdam, 1: 3-52

Martinelli DP, Spers EE, Costa AF (2000) Ypióca - Introduzindo uma Bebida Genuinamente Brasileira no Mercado Global. In: "O desafio das exportações”. PENSA/USP, São Paulo

Matsuoka S, Garcia AAF, Calheiros GC (1999) Hibridação em canade-açúcar. In: Borém A (ed) Hibridação Artificial de Plantas. Viçosa: Editora UFV, 221-254

Matsuoka S, Garcia AAF, Arizono H (2005) Melhoramento da canade-açúcar. In: Borém A (ed) Melhoramento de espécies cultivadas. Editora UFV, Viçosa, pp 205-251

McIntyre CL, Jackson PA (2001) Low level of selfing found in a sample of crosses in Australian sugarcane breeding programs. Euphytica 117:245-249

Midmore DJ (1980) Effects of photoperiod on flowering and fertility of sugarcane (Saccharum spp.). Field Crops Res 3:65-81
Mohan Naidu K, Sreenivasan TV (1987) Conservation of sugarcane germoplasm. In: Copersucar International Sugarcane Breeding Workshop, São Paulo: Copersucar pp 33-53

Molinari HBC, Marur CJ, Daros E, Campos MKF, Carvalho JFRP, Bespalhok Filho JC, Pereira LFP, Vieira LGE (2007) Evaluation of the stress-inducible production of proline in transgenic sugarcane (Saccharum spp.): osmotic adjustment, chlorophyll fluorescence and oxidative stress. Physiol Plant 130:218-229

Mongelard JE (1968) The effect of different water regimes on the growth of two sugar cane varieties. Int Soc Sug Cane Technol Proc 13:643-651

Moore PH (1976) Studies on sugarcane pollen. II. Pollen storage. Phyton, Argentina 34:71-80

Moore PH (1987a) Anatomy and morphology. In: Heinz DJ (ed) Sugarcane improvement through breeding. Elsevier, Amsterdam, pp 85-142

Moore PH (1987b) Physiology and control of flowering. In: Copersucar International Sugarcane Breeding Workshop, São Paulo:Copersucar pp 103-128

Moore PH (1999) Progress and development in sugarcane biotechnology. In: Singh V, Kumar V (eds) Proc Int Soc Sugar Cane Technol 23: 241-258

Moore PH, Nuss KJ (1987) Flowering and flower synchronization. In: Heinz DJ (ed) Sugarcane improvement through breeding. Elsevier, Amsterdam, pp 273-311

Moore PH, Osgood RV (1989) Prevention of flowering and increasing yield of sugarcane by application of Ethephon (2-Chloroethylphosphonic acid). J Plant Growth Regul 8:205-210

Mozambani AE, Pinto AS, Vanzolini S, Mattiuz CFM (2006) História e morfologia da cana-de-açúcar. In: Segato SV, Pinto AS, Jendiroba E, Nóbrega JCM (eds) Atualização em produção de cana-de-açúcar. Piracicaba 1: 11-18

Mukherjee SK (1957) Origin and distribution of Saccharum. Bot Gaz 119:55-61

Mukherjee SK (1958) Revision of Erianthus Michx. (Gramineae). Lloydia 21:157-188

Nakano O, Silveira Neto S, Carvalho RPL, Baptista GC, Berti Filho E, Parra JRP, Zucchi RA, Alves SB, Vendramim JD, Marchini LC, Lopes JRS, Omoto C, Gallo D (2002) Entomologia agrícola, v. 10. FEALQ, Piracicaba, p 920

Nardin RR (2007) Torta-de-filtro aplicada em argissolo e seus efeitos agronômicos em duas variedades de cana-de-açúcar colhidas em duas épocas. IAC, Campinas, p 39

Nobrega JCM de, Dornelas MC (2006) Biotecnologia e Melhoramento da Cana-de-Açúcar. In: Segato SV, pinto AS, Jendiroba E, Nóbrega JCM (eds) Atualização em produção de cana-de-açúcar. Piracicaba 1: 39-56

Nutt KA, Allsopp PG, McGuie TK, Shepherd KM, Joyce PA, Taylor GO, McQualter RB, Smith GR (1999) Transgenic sugarcane woth increasing resistance to canegrubs. In: Hogarth DM (ed) Proc Aust Soc Sugarcane Technol 21: 171-176

OGTR (2008) The biology of the Saccharum spp. (Sugarcane). http:// www.health.gov.au/internet/ogtr/publishing.nsf/Content/sugar cane-3/\$FILE/biologysugarcane08.pdf Cited 11 Jan 2011

Olivares-Villegas JJ, Powell RP, Berding N, Morgan T, Schmidt S, Bonnett GD (2008) Determining the limits of Saccharum seed germination. Symposium handbook of the 10th International Symposium on the Biosafety of Genetically Modified Organisms, Wellington, New Zealand. 117. http://www.isbgmo.info/assets_ isbgmo_symposium_handbook.pdf. Cited 04 Aug 2010

Oliveira ACG (2007) Efeitos do processamento térmico e da radiação gama na estabilidade físicoquímica, microbiológica e sensorial de caldo de cana puro e adicionado de suco de frutas, armazenado sob refrigeração. ESALQ, Piracicaba, p 105

Ometto AR, Mangabeira JAC, Hott MC (2005). Mapeamento de potenciais de impactos ambientais da queima de cana-de-açúcar no Brasil; Anais do XII Simpósio Brasileiro de Sensoriamento 
Remoto, Goiânia, Brasil. http://marte.dpi.inpe.br/col/ltid.inpe.br/ sbsr/2004/11.19.16.07/doc/2297.pdf. Cited 10 Jan 2011

Orlando Filho J (1983) Nutrição e Adubação de Cana-de-açúcar no Brasil. Piracicaba. Instituto do Açúcar e do Álcool/Planalsucar. p 363

Pate FM (1982) Value of treating bagasse with steam pressure for cattle feed. Trop Agric 59:293-297

Paturau J (1969) By-products of sugar industry. Amsterdam Elsevier, p 247

Pilger R (1940) Gramineae: Paniceae, Arthropogoneae, Andropogoneae, Maydeae, in Engler \& Prantl Nat. Pflazenfamilien

Piperidis G, D'Hont A (2001) Chromosome composition analysis of various Saccharum interspecific hybrids by genomic in situ hybridization (GISH). Proc Int Soc Sugcane Technol 24:565-566

Pires RCM, Arruda FB, Sakai E (2008) Irrigação e drenagem. In: DinardoMiranda LL, Vasconcelos ACM, Landell MGA (eds) Cana-deaçúcar. Instituto Agronômico de Campinas, Campinas, p 882

Pradella JGC (2006) Biopolímeros e Intermediários Químicos. Centro de Gestão e Estudos Estratégicos. http://www.anbio.org.br/pdf/2/ tr06_biopolimeros.pdf. Cited 10 Jan 2011

Quast DG (1986) Tipos de açúcar produzidos no Brasil. Aliment Tecnol 10:49-52

Rao PS (1980) Fertility seed storage and seed viability in sugarcane In: Proc Int Soc Sug Cane Technol 1236-1240

Rao JT, Kandasamy PA, Kumari RK (1957) Tannin in root tip as a probable geneic character of Erianthus. Curr Sci 26:219-220

Renvoize SA (1984) The grasses of Bahia. Kew: Royal Botanic Gardens, p 301

Ricaud C, Autrey LJC (1989) Gumming disease. In: Ricaud C, Egan BT, Gillaspie AG Jr, Hughes CG (eds) Diseases of sugar cane: major diseases. Elsevier Science Publishers, Amsterdam, pp 21-33

Ricaud C, Ryan CC (1989) Leaf scald. In: Ricaud C, Egan BT, Gillaspie AG Jr, Hughes CG (eds) Diseases of sugar cane: major diseases. Elsevier Science Publishers, Amsterdam, pp 39-58

Ripoli MLC, Ripoli TCC (2008) Sistemas de colheita. In: DinardoMiranda LL, Vasconcelos ACM, Landell MGA (eds) Cana-deaçúcar. Instituto Agronomico de Campinas, Campinas, p 882

Roach BT, Daniels J (1987) A review of the origin and improvement of sugarcane. In: Copersucar International Sugarcane breeding Workshop 1: 1-31

Rodrigues D, Ortiz L (2006) Em direção à sustentabilidade da produção de etanol de cana de açúcar no Brasil. http://www. natbrasil.org.br/Docs/biocombustiveis/sustentabilidade_etanol_ port.pdf. Cited 10 Jan 2011

Romeis J, Bartsch D, Bigler F, Candolfi MP, Gielkens MMC, Hartley SE, Hellmich RL, Huesing JE, Jepson PC, Layton R, Quemada H, Raybould A, Rose RI, Schiemann J, Sears MK, Shelton AM, Sweet J, Vaituzis Z, Wolt JD (2008) Assessment of risk of insectresistant transgenic crops to nontarget arthropods. Nat Biotechnol 26:203-208

Rugg-Gunn AJ, Murray JJ (1983) The role of sugar in the aetiology of dental caries: 2. The epidemiological evidence. J Dent 11:190 199

Santos AS (2008) Doenças causadas por fungos. In: Dinardo-Miranda LL, Vasconcelos ACM, Landell MGA (eds) Cana-de-açúcar. Instituto Agronomico de Campinas, Campinas, p 882

Scarpari MS, Beauclair EGF (2008) Anatomia e Botânica. In: DinardoMiranda LL, Vasconcelos ACM, Landell MGA (eds) Cana-deaçúcar. Instituto Agronomico de Campinas, Campinas, p 882

SEBRAE (2005) O Novo Ciclo da Cana: Estudo sobre a competitividade do sistema agroindustrial da cana-de-açúcar e prospecção de novos empreendimentos. Brasília: IEL/NC, p 337
Segalla AL (1964) Botânica, melhoramento e variedades. In: Malavolta et al (eds) Cultura e adubação da cana-de-açúcar. Instituto Brasileiro de Potassa, São Paulo, pp 61-98

Sigma-Aldrich (2007a) Sucrose safety data sheet. http://www.sigmaal drich.com/MSDS/MSDS/DisplayMSDSPage.do. Cited 10 Jan 2011

Sigma-Aldrich (2007b) Ethanol safety data sheet. http://www.sigmaal drich.com/MSDS/MSDS/DisplayMSDSPage.do. Cited 10 Jan 2011

Smith LB, Wasshausen DC, Klein RM (1982) Gramíneas. Gêneros: 85. Paspalum até Zea. Flora Ilustrada Catarinense. Herbário Barbosa Rodrigues, Itajaí, p 504

Soccol CR, Schwab A, Katsoka CE (1990) Avaliação microbiológica do caldo de cana na cidade de Curitiba. Boletim do Centro de Pesquisa e Processamento de Alimentos. Curitiba 8(2):116-125

Sreebny LM (1982) Sugar availability, sugar consumption and dental carries. Comm Dent oral Epidemiol 11:190-199

Sreenivasan TV, Ahloowalia BS, Heinz DJ (1987) Cytogenetics. In: Heinz DJ (ed) Sugarcane improvement through breeding. Elsevier, Amsterdam, pp 211-254

Sun SSM, Maretzki A, Nagai C, Houtchens K, Bidney D (1993) Transformation of Saccharum spontaneum by particle bombardment. Sugarcane 5:1-7

The Plant List (2010) Version 1. http://www.theplantlist.org/ Cited 10 Jan 2011

Thompson GD (1964) Water use by sugarcane. S Afr Sugar J 60:627-635

Tomkins JP, Yu Y, Miller-Smith H, Frisch DA, Woo SS, Wing RA (1999) A bacterial artificial chromosome library for sugarcane. Theor Appl Genet 99:419-424

USDA (2008) Federal Noxious Weed List. http://www.aphis.usda.gov/ plant_health/plant_pest_info/weeds/downloads/weedlist2006.pd. Cited 10 Jan 2011

Valsechi O, Oliveira ER (1964) A cana-de-açúcar como matériaprima. In: Malavolta et al (eds) Cultura e adubação da cana-deaçúcar. Instituto Brasileiro de Potassa, São Paulo, pp 319-368

van Dillewijn C (1952) Botany of sugar cane. Waltham: Chronica Botanica, p 371

Venkatraman RSTS (1922) Germination and preservation of sugarcane pollen. Agric J India 17:127-132

Vettore AL, da Silva FR, Kemper EL, Arruda P (2001) The libraries that made SUCEST. Genet Mol Biol 24(1-4):1-7

Vijayalakshmi U, Rao JT (1963) Phytosterols in the leaves of Saccharum and allied genera. Int soc Sug Cane Technol Proc 11:578-582

Villaseñor JL, Espinosa-Garcia F (2004) The alien flowering plants of Mexico. Divers Distrib 10:113-123

Waldron JC, Glasziou KT (1972) Isozymes as a method of varietal identification in sugarcane. Proc ISSCT 14:249-256

Webster R, Shaw RB (1995) Taxonomy of the native north American species of Saccharum (Poaceae:Andropogoneae). Sida 16 (3):551-580

Williams CA, Harborne JB, Smith P (1974) The taxonomic significance of leaf flavonoids in Saccharum and related genera. Phytochemistry 13:1141-1149

Wu L, Birch RG (2007) Doubled sugar content in sugarcane plant modified to produce a sucrose isomer. Plant Biotech J 5:109-117

Xavier MA, Rodrigues J, Sanguino A (2008) Viveiro de Mudas. In: Dinardo-Miranda LL, Vasconcelos ACM, Landell MGA (eds) Canade-açúcar. Instituto Agronomico de Campinas, Campinas, p 882

Zhang SZ, Yang BP, Feng CL, Chen RK, Luo JP, Cai WW (2006) Expression of the Grifola frondosa trehalose synthase gene and improvement of drought-tolerance in sugarcane (Saccharum officinarum L.). J Integrat Plant Biol 48(4):453-459 